\title{
Birinci Dünya Savaşında Mimarlık Yapmak: Vedad (Tek) Bey'in Harbiye Nezareti’ne Bağlı Çalışmaları*
}

\section{Being an Architect During World War I: Vedad (Tek) Bey's Works for the Ministry of War}

\author{
Müjde Dila Gümüşs ${ }^{1}$ (D)
}

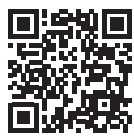

* Bu çalıșma, Nevsehir Hacı Bektaș Vel Üniversitesi'de 7-9 Ekim 2020'da gerçekleștirilen 24. Uluslararası Ortaçağ ve Türk Dönemi Kazıları ve Sanat Tarihi Araştırmaları Sempozyumu'nda "1. Dünya Savașında Mimarlık Yapmak: Vedad (Tek) Bey'in Harbiye Nezâreti'ne Bağlı Çalışmaları" bașlığıyla sözlü bildiri olarak sunulmuștur. Tam metni daha önce yayınlanmamış olan çalışma, yeni bulgu ve değerlendirmelerle geliştirilerek makale biçimine getirilmiştir.

\section{öz}

Mehmed Vedad (Tek) Bey, verimli kariyeri boyunca pek çok önemli görev üstlenmiştir. Bunlar arasında Harbiye Nezareti mimarlığı da bulunmaktadır. Söz konusu görev, I. Dünya Savaşı yıllarına denk gelmesi bakımından dikkat çekicidir. Vedad Bey'in kariyerindeki bu dönem, herhangi bir detaylı araştırmaya konu olmamıştır. Bu makale, Vedad Bey'in Harbiye Nezareti mimarlığı döneminde hazırladığı projelere ve üstlendiği görevin kapsamını aydınlatmaya odaklanmaktadır. 1915-1918 yılları arasında Vedad Bey'in Seyr-i Sefain İdaresi için çeşitli projeler hazırladığı, önceki çalışmalarda tespit edilmiştir. Bunlardan Moda İskelesi, Haydarpaşa İskelesi ve Seyr-i Sefain Acentesi inşa edilirken, Kadıköy İskelesi tasarım aşamasında kalmıştır. Vedad Bey'in Harbiye Nezareti için 19151916 yıllarında hazırladığı “üçüncü sınıf istasyon” projesi, bu araştırma kapsamında tespit edilmiş olup, makalede detaylıca incelenmiştir. Milli Mimari üslubunun sade bir örneği olarak tasarlanmış istasyon binasının, Ankara-Erzurum arasında inşa edilmek istenen demiryoluyla ilişkili bir proje olduğu anlaşılmaktadır. İncelenen bir başka örnek, 1915 yılında inşa edilmiş olan Enver Paşa Köşkü'dür. Bu yapı, yuvarlak kemerli ve iyonik sütun başlıklı girişiyle dönemin mimari modasından uzaklaşması bakımından dikkat çekicidir. Vedad Bey'in Harbiye Nezareti'ndeki görevi kapsamında gerçekleştirdiği tespit edilen diğer iki faaliyet, Veliefendi Hipodromu için kapsamlı bir proje hazırlaması ve Batum'a giderek ordunun mimari ihtiyaçlarını üzerine çalışmasıdır. 1914 yılında hazırlanan bir askeri mimarlık el kitabına da katkı sunduğu düşünülmektedir. Bu sebeple söz konusu kitaptaki mimari çizimlerin üslup özellikleri, kısaca ele alınmıştır.

Anahtar kelimeler: Vedad Tek, Milli Mimari Dönemi, 1. Dünya Savaşı, Geç Dönem Osmanlı Mimarlığı, Harbiye Nezareti

\section{ABSTRACT}

Mehmed Vedad (Tek) Bey undertook several essential tasks and roles during his career. Among these, he served as the Ministry of War's architect, which is particularly noteworthy as he held the post during the First World War. This era in Vedad Bey's career has not yet been the subject of detailed research. This article focuses on the architectural projects he prepared during his appointment at the Ministry of War, as well as his responsibilities in that position. Previous studies have shown that, between 1915 and 1918, Vedad Bey worked on various projects 
for the Seyr-i Sefain (Maritime) Administration. While Moda Pier, Haydarpaşa Pier, and the Seyr-i Sefain Agency were built, Kadıköy Pier remained unrealized. Vedad Bey's "third-class station" project, presented for the first time in this article, is examined in detail. The station, designed as a modest building in the Turkish National Style, was intended for the railway to be built between Ankara and Erzurum. Another project examined is the Enver Pasha Mansion of 1915. This structure is remarkable in terms of its divergence from contemporary architectural fashion with its round-arched and ionic column-headed entrance. Two other activities identified as undertaken by Vedad Bey for the Ministry of War are preparing comprehensive plans for the Veliefendi Hippodrome and his survey in Batumi to investigate the army's architectural requirements. It is thought that Vedad Bey also contributed to a military architecture handbook prepared in 1914. Accordingly, the architectural drawings in this book are explored briefly from a stylistic perspective.

Keywords: Vedad Tek, Turkish National Style, World War I, Late Ottoman Architecture, Ministry of War

\section{EXTENDED ABSTRACT}

Mehmed Vedad (Tek) Bey, one of the best-known architects of late Ottoman and early Republican Turkey, undertook several essential tasks and roles during a productive career. Among his positions were a professorship at the Fine Arts Academy (Sanayi-i Nefise Mektebi), the Ministry of Post and Telegraph's chief architect, and the chief architect to Sultan Mehmed Reşad V. After the declaration of the Turkish Republic, he received several commissions for buildıngs in Ankara from Mustafa Kemal Atatürk and the People's Party (Halk Fırkası).

This paper, however, will focus on Vedad Bey's role as the Ministry of War's (Harbiye Nezareti) architect between 1915 and 1918, a noteworthy period as it coincided with World War I. Vedad Bey's years in the Ministry of War have not yet been the subject of detailed research. Accordingly, this paper will explore Vedad Bey's architectural output and its stylistic features in the context of the Turkish National Style and seek to understand his responsibilities while working for the Ministry of War.

Six topics pertaining to Vedad Bey's architectural works and commissions will be examined. The first concentrates on projects related to the Administration of the Seyr-i Sefain, a maritime transportation organization in İstanbul that was overseen by the Ministry of War during this period. Vedad Bey prepared various projects for this organization between 1915 and 1918: the Seyr-i Sefain Agency building and piers at Moda, Haydarpaşa, and Kadıköy. While Kadıköy Pier remained unrealized, the other three were constructed.

Until its demolition in 1958, the Seyr-i Sefain Agency building was located in Karaköy. Photographs show that the façades mostly adhered to common features of the Turkish National Style. Nonetheless, two of the three façades were organized in an asymmetrical manner, which was not typical of the Turkish National Style and reflects Vedad Bey's unique architectural approach.

Vedad Bey used historical architectural and ornamental elements in Haydarpaşa and Moda Piers but in two different ways. While Haydarpaşa Pier appears as a highly ornamented building with a rich repertoire of historical references, Moda Pier draws attention with its four completely individually designed façades. Some components of the piers were produced in the workshops of the Ministry of War. 
Second, the article will examine a railway station project of Vedad Bey titled "the third-class station building," and will thus represent the first academic publication on this subject. Plans of the first and second floors with the descriptions of each room enable a deep understanding of the building's functioning. Façade drawings indicate the modest appearance of Vedad Bey's design with features typical of the Turkish National Style. While a document from the Presidency Ottoman Archive contains hints regarding the construction of the station, no data was found on the project's completion.

The third topic highlights the Enver Pasha Mansion. Located in Orkatöy, Vedad Bey built the mansion in 1915. Although its construction was not officially commissioned by the Ministry, since the building's patron was the Minister of War it relates directly to Vedad's work in the Ministry. Surprisingly, the Enver Pasha Mansion's façade does not exhibit elements of the Turkish National Style. Instead, of pointed arches and muqarnas capitals, it features a rounded arched entrance with ionic capitals. That said, the Turkish bath within, decorated with tiles inspired by seventeenth-century Ottoman originals, links the mansion with the Turkish National Style.

The last three topics briefly consider the Veliefendi Hippodrome project, a military architecture book prepared anonymously in 1914, and Vedad Bey's survey in Batum with Enver Paşa to identify the army's architectural needs. Although only limited information exists on these three topics, they are included as they provide additional insight on the scope of Vedad Bey's work in the Ministry.

Vedad Bey thus prepared at least seven architectural projects and made at least two longdistance surveys during the term of his appointment. The Ministry of War made use of its own resources and staff when undertaking construction projects. Except for the Enver Pasha Mansion, all five completed projects were executed in the National Style. While the Seyr-i Sefain Agency building and the piers were prepared in the National Style, they uniquely reflected Vedad Bey's own architectural approach. Similarly, the train station appears to have been a typical and modest example of the National Style, as were the projects in the military architecture handbook. 


\section{Giriş}

Geç Osmanlı ve erken Cumhuriyet dönemi mimarlık tarihinin en tanınmış aktörlerinden Mehmed Vedad (Tek) Bey, verimli kariyeri boyunca pek çok önemli görev üstlenmiştir. Bu görevler arasında, uzun yıllar sürdürdüğü Sanayi-i Nefise Mektebi hocalığı, sermimar-1 hazret-i şehriyari unvanıyla üstlendiği saray baş mimarlığı (1909-1914), Cumhuriyet’in ilanından sonra Mustafa Kemal Atatürk ve Cumhuriyet Halk Fırkası için Ankara'da gerçekleştirdiği çalışmalar sayılabilir. Bu makale, Vedad Bey'in detaylı bir araştırmaya konu edilmemiş olan Harbiye Nezareti baş mimarlığı dönemine odaklanmaktadır. ${ }^{1}$ Konuyu ilgi çekici kılan başlıca sebep ise, Vedad Bey’in söz konusu görevde I. Dünya Savaşı yıllarında bulunmuş olmasıdır. Makale kapsamında, Vedad Bey'in bu süreçteki çalışma koşullarının ve görevi kapsamında gerçekleştirdiği mimari üretiminin mümkün olduğunca aydınlatılması amaçlanmaktadır. Vedad Bey'in Harbiye Nezareti ile ilişkili çalışmaları; Seyr-i Sefain İdaresi ile ilişkili projeler, Harbiye Nezaret-i Celilesi Demir Yolları üçüncü sınıf istasyon binası, Enver Paşa Köşkü, Veliefendi Hipodromu projesi, ordunun ihtiyaçlarını tespit etmek üzere Batum'da saha çalışması ve askeri mimarlık el kitabı alt başlıkları altında incelenecektir. Ele alınan başlıklardan kimilerine ilişkin veriler kısıtlı olsa da, Vedad Bey'in Harbiye Nezareti için çalıştığı dönemdeki görev kapsamına ilişkin bir çerçeve çizmeye katkı sunmaları bakımından, araştırmanın dışında bırakılmamışlardır. Araştırmanın birincil kaynaklarını ise, Cumhurbaşkanlığı Devlet Arşivleri’nden, Anıtlar Kurulu Genel Müdürlüğü Arşivi’nden ve Bodrum Mimarlık Kitaplığı Vedad Tek Arşivi’nden sağlanan belgeler meydana getirmektedir.

\section{Vedad Bey’in Harbiye Nezareti Baş Mimarlığı}

Vedad Bey, Harbiye Nezareti'ndeki görevine başlamadan önceki beş yıl boyunca doğrudan saraya bağlı olarak çalışmış; 1909-1914 yılları arasında padişahın baş mimarı olarak, 1914 yılında ise Emlak-1 Hümâyun mimarı olarak sarayda görev yapmıştı. ${ }^{2}$ Saraydan ayrılarak Harbiye Nezareti için çalışmaya başlamasında önemli bir etken, Enver Paşa ile iyi ilişkileri olmuştur. Enver Paşa'nın Vedad Bey’i desteklediğini, hem Nihat Tek, hem de Yusuf Razi Demirbel çeşitli yazılarında belirtmişlerdir. ${ }^{3}$

1 Vedad Bey'in Harbiye Nezareti baş mimarı olarak görev yaptığı, kendisi üzerine yapılan ilk akademik araştırmada ortaya koyulmuştur. Süha Özkan, "Mimar Vedat Tek (1873-1942)," Mimarlık 11-12 (1973), 48.

2 Afife Batur, "Kimliğinin İzinde II: Yeniyi Aramak," M. Vedad Tek Kimliğinin İzinde Bir Mimar içinde, ed. Afife Batur (İstanbul: Yapı Kredi Yayınları, 2003), 147. Vedad Bey'in Sultan V. Mehmed Reşad'ın baş mimarı olarak görev yaptığı döneme ilişkin geniş bilgi için bkz. Müjde Dila Gümüş, "II. Meşrutiyet’te Saray İçin Çalışmak: Vedad (Tek) Bey'in Sermimarlık Dönemi” (Doktora Tezi, İstanbul Üniversitesi, 2018).

3 Nihat Tek Vedad Bey'in oğlu, Yusuf Razi Demirbel ise Vedad Bey'in ağadeyidir. Yusuf Razi Demirbel, "Prof. Mimar M. Vedad Tek," Arkitekt 129-130 (1941), 231. Nihat Tek, Enver Paşa'nın Vedad Bey'in Valikonağı'ndaki evini çok beğendiğine, Sultan V. Mehmet Reşad ile beraber Vedad Bey'in evine gittiklerine ve Vedad Bey'i saray mimarlığından atmak üzere açılan bir soruşturmanın özellikle Enver Paşa yurtıı̧̧ndayken başlatıldığına dair anılarını kaleme almıştır. Nihat Tek, "N. Nahir Sılan'a Mektup," M. Vedad Tek Kimliğinin İzinde Bir Mimar içinde, ed. Afife Batur (İstanbul: Yapı Kredi Yayınları, 2003), 390-391. Ayrıca, Vedad Bey'in tasarımı olan Tayyare Şehitleri Abidesi'nin temelini Enver Paşa, Vedad Bey ile beraber atmıştır. "Âbide-i Şühedâ,” Tanin, 3 Nisan 1914, 1. Tayyare Şehitleri Abidesi, Vedad Bey V. Mehmed Reşad'ın sermimarı olarak çalıştığı döneme ait bir eser olduğundan dolayı bu araştırmaya dahil edilmemiştir. 
Vedad Bey, önce tam olarak tespit edemediğimiz bir süre Harbiye Nezareti için çalışmış, Ağustos 1916'da ise “Levazımat-1 Umumiye Dairesi İnşaat Şubesi sermimarlığına” beş bin kuruş maaş ve iki bin kuruşluk bir tahsisat ile atanmıştır. Görevi süresince, Harbiye Nezareti'nin inşa ettirdiği birkaç binanın projesini hazırladığını ve inşaatlarına nezaret ettiğini, ayıca dördüncü dereceden Mecidiye nişanıyla taltif edildiğini, savaşın sona ermesi ile açığa alındığını, kendi hazırladığı tercüme-i hal varakasında belirtmiştir. ${ }^{4}$ Açığa alınma sebebini ise mütareke döneminde büyük inşaat faaliyetleri gerçekleştirilmeyecek olmasıyla açıklamıştır. ${ }^{5}$

Harbiye Nezareti için proje hazırlarken ve yapıların inşasına nezaret ederken, Vedad Bey'in beraberinde çalışan başka mimar ve kalfalar da olmalıdır. Vedad Bey’in ekibine ilişkin bu araştırma kapsamında ulaşılabilen tek veri, Birinci Dünya Savaşı sürerken Sanayi-i Nefise Mektebi Mimarlık Şubesi'nde öğrenci olan Refik (Gökhan) Bey’in verdiği bir röportajda bulunmaktadır: "Sanayii Nefise'ye girdim... O sırada askere alındım. Harbiye Nezareti inşaat şubesine aldı beni Mimar Vedat Bey (1916)... Biz böyle gidip gelirken savaş bitmiş oldu, biz de ikinci sınıfa başladık." Refik Bey'in aktardıklarından, Vedad Bey'in, Sanayi-i Nefise Mektebi Mimarlık Şubesi'nde eğitim görürken askere alınan öğrencilerden en az bir tanesinin, kendisi ile çalışmak üzere Harbiye Nezareti İnşaat Şubesi’nde görevlendirilmesini sağladığı anlaşılmaktadır. Bu noktada, II. Meşrutiyet döneminde Evkaf Nezareti baş mimarlığını yürütmüş olan Kemâleddin Bey’in, bir kısmı kendi öğrencilerinden oluşan bir fen heyeti ile çalıştığını; hatta Evkaf Nezareti mimarlarının Kemâleddin Bey başkanlığındaki çalışma biçimine, öğretici yönüne vurgu ile "Kemâleddin okulu" yakıştırılması yapıldığını hatırlamak anlamlı olacaktır. ${ }^{7}$ Harbiye Nezareti’nce yürütülen inşa ve tamir faaliyetleri Evkaf Nezareti kadar yoğun olmamışsa da, makalede ele alınacak projeleri hazırlama ve inşa süreçlerini Vedad Bey’in tek başına yürütmüş olması da mümkün görünmez.

\section{Vedad Bey'in Harbiye Nezareti'ne Bağlı Çalışmaları}

\section{A. Seyr-i Sefain İdaresi ile İlişkili Projeler}

Vedad Bey’in, Harbiye Nezareti için çalıştığı dönemde, en yoğun inşa faaliyetini Seyr-i Sefain İdaresi için gerçekleştirdiği görülmektedir. İstanbul'da şehir içi deniz ulaşımını sağlayan kurumlardan biri olan Seyr-i Sefain İdaresi, 1913 yılında Sadrazam ve Harbiye Nazırı Mahmud Şevket Paşa tarafından Harbiye Nezareti'ne bağlanmıştır. ${ }^{8}$ Bu durumun sonucunda, Vedad Bey, Seyr-i Sefain İdaresi ile ilişkili bir grup yapı projelendirmiştir. Bunlar; Seyr-i Sefain Acente binası, Moda İskelesi, Haydarpaşa İskelesi ve Kadıköy İskelesi' dir. ${ }^{9}$

4 Batur, "Kimliğinin İzinde II," 147.

5 Vedad Bey 3 Kanunusani 1339 (3 Ocak 1923) tarihinde İstanbul Kumandanlığı’na yazdığı dilekçede “... Harbiye Nezareti Levazım Dördüncü İnşaat Şubesi sermimar ve fen müşaviri iken mütarekeden bir müddet sonra büyük inşaat olmadığı cihetle sermimara adem-i lüzumundan bahisle açığa çıkarıldım.” ifadesini kullanmıştır. Bodrum Mimarlık Kitaplığı, Vedad Tek Arşivi, Süha Özkan ve Pelin Derviş Koleksiyonu. (Bkz EK1).

6 Behçet Ünsal, “70 Yaşını İdrak Eden Mimarlar II: Boğaziçi’nde Bir Mimar,” Arkitekt 352 (1973), 179.

7 Yıldırım Yavuz, Mimar A. Kemalettin Imparatorluk'tan Cumhuriyet'e (Ankara: TMMOB Mimarlar Odası ve Vakıflar Genel Müdürlüğ̈ Yayınları, 2009), 29.

8 Eser Tutel, Seyr-i Sefain Öncesi ve Sonrası (İstanbul: İletişim Yayınları, 1997), 134.

9 Süha Özkan, “Reddedilen Bir Mimar: Vedat Tek,” Şehir VII (1987), 27. Batur, “Kimliğinin İzinde II,” 157. 


\section{Seyr-i Sefain Acente Binası}

1915 yılında Karaköy Köprübaşı'nda inşa edilmiş olan Seyr-i Sefain Acentesi, 1958’de Menderes dönemi imar hareketi kapsamında yıkılmıştır. ${ }^{10}$ Giriş katının üzerine üç katlı olan yapıda, betonarme karkas sistemi kullanılmıştır. ${ }^{11}$ Yusuf Razi Demirbel, yapının inşa edileceği zeminin "kâmilen çürük ve çamur" olduğunu, bu sebeple temelinde betonarme kullanıldığını aktarmıştır. ${ }^{12}$

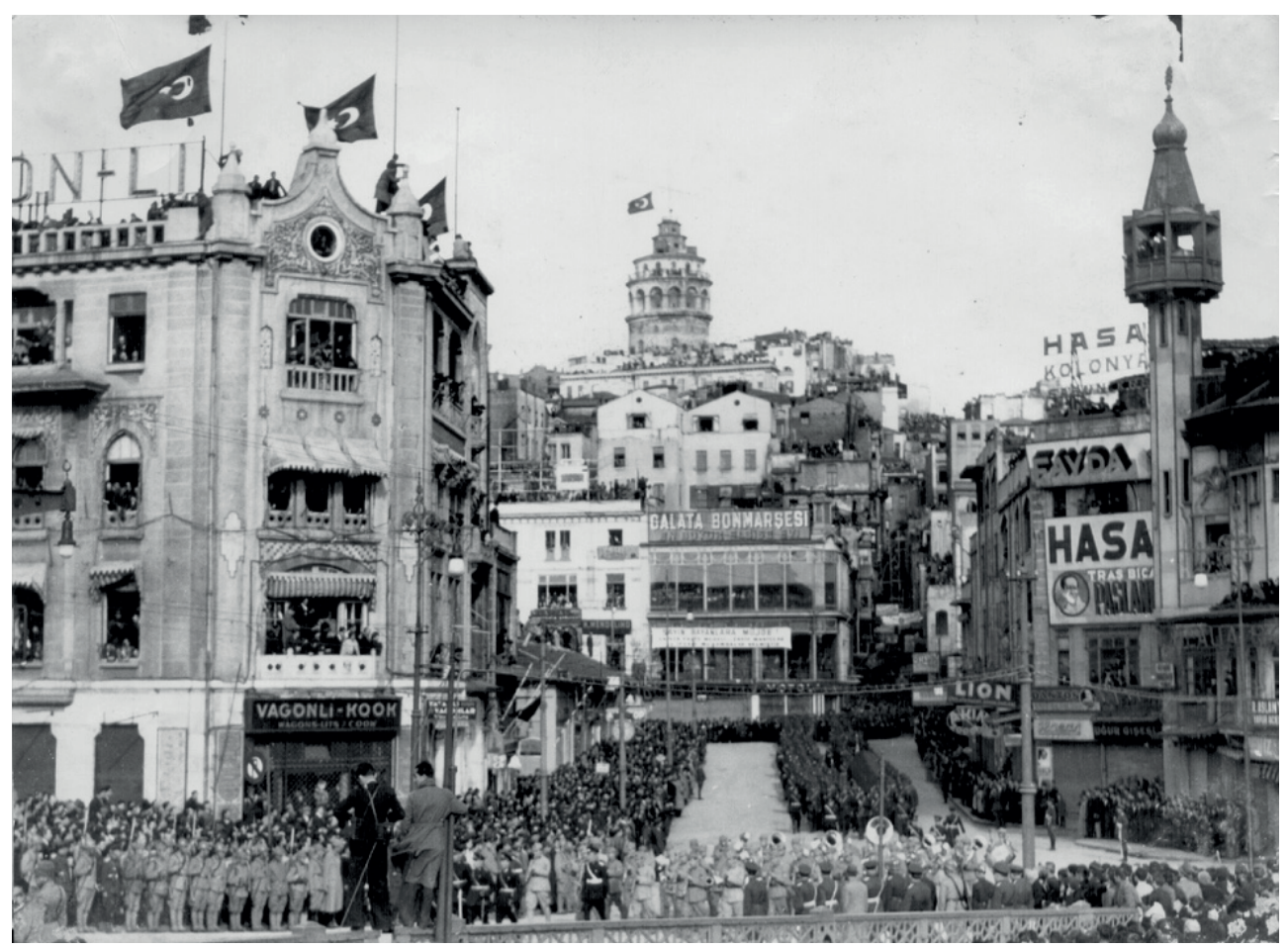

Görsel 1: Seyr-i Sefain Acentesi’nin 1938 yılındaki görünümü. (SALT Araştırma)

10 Batur, "Kimliğinin İzinde II," 154.

11 Vedad Bey'in 1914-16 yıllarında inşa edilen yapılarından Mesadet Han, Muradiye Han ve Seyr-i Sefain Acentesi binası, betornarme karkas sisteminin İstanbul'daki erken örneklerindendir. Batur, "Kimliğinin İzinde II," 147-48.

12 Demirbel, "Prof. Mimar M. Vedad," 232. 


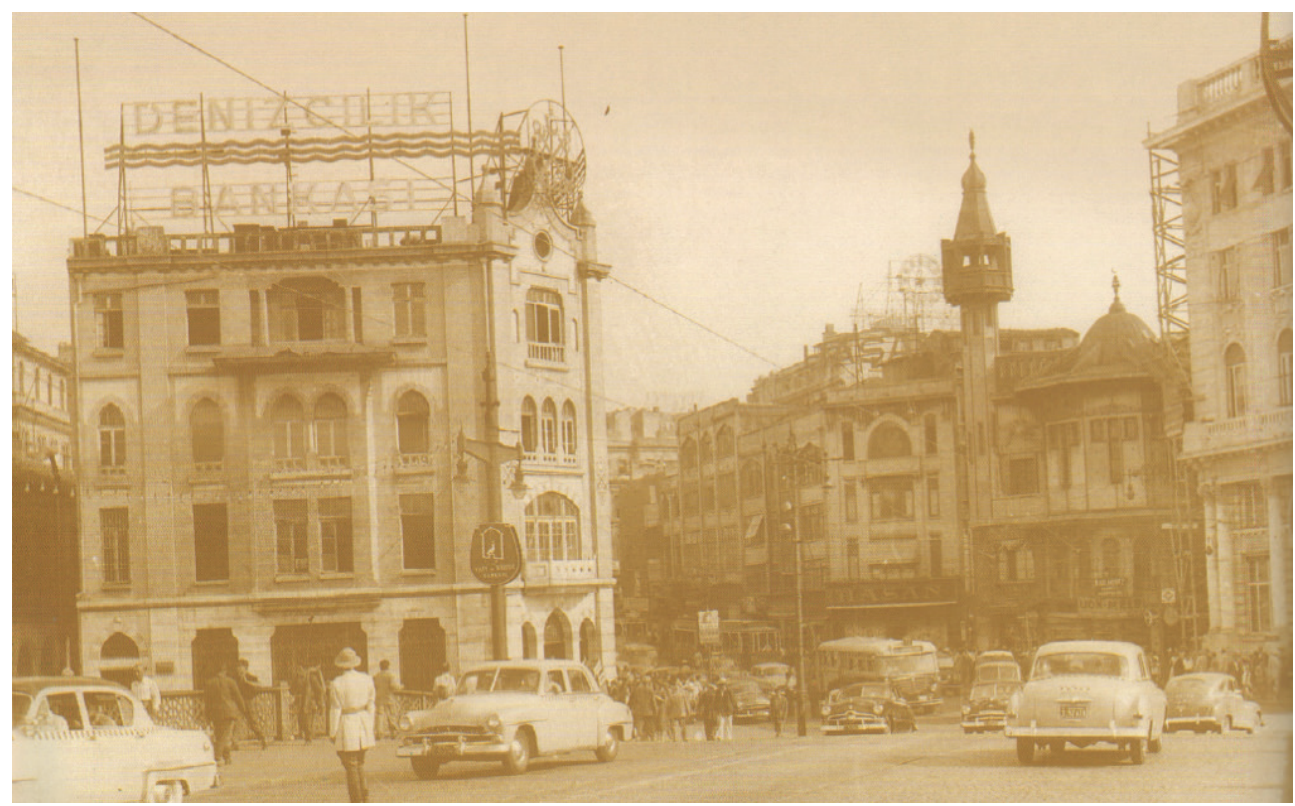

Görsel 2: Seyr-i Sefain Acentesi'nin denize bakan cephesi, 1940'lar veya 1950'ler. (Nobuo Misawa, "Japon Ticaret Sergisi (1929-1937): İstanbul'daki Japon İzleri," 1453 İstanbul Kültür ve Sanat Dergisi 7, 2010, 42.) 


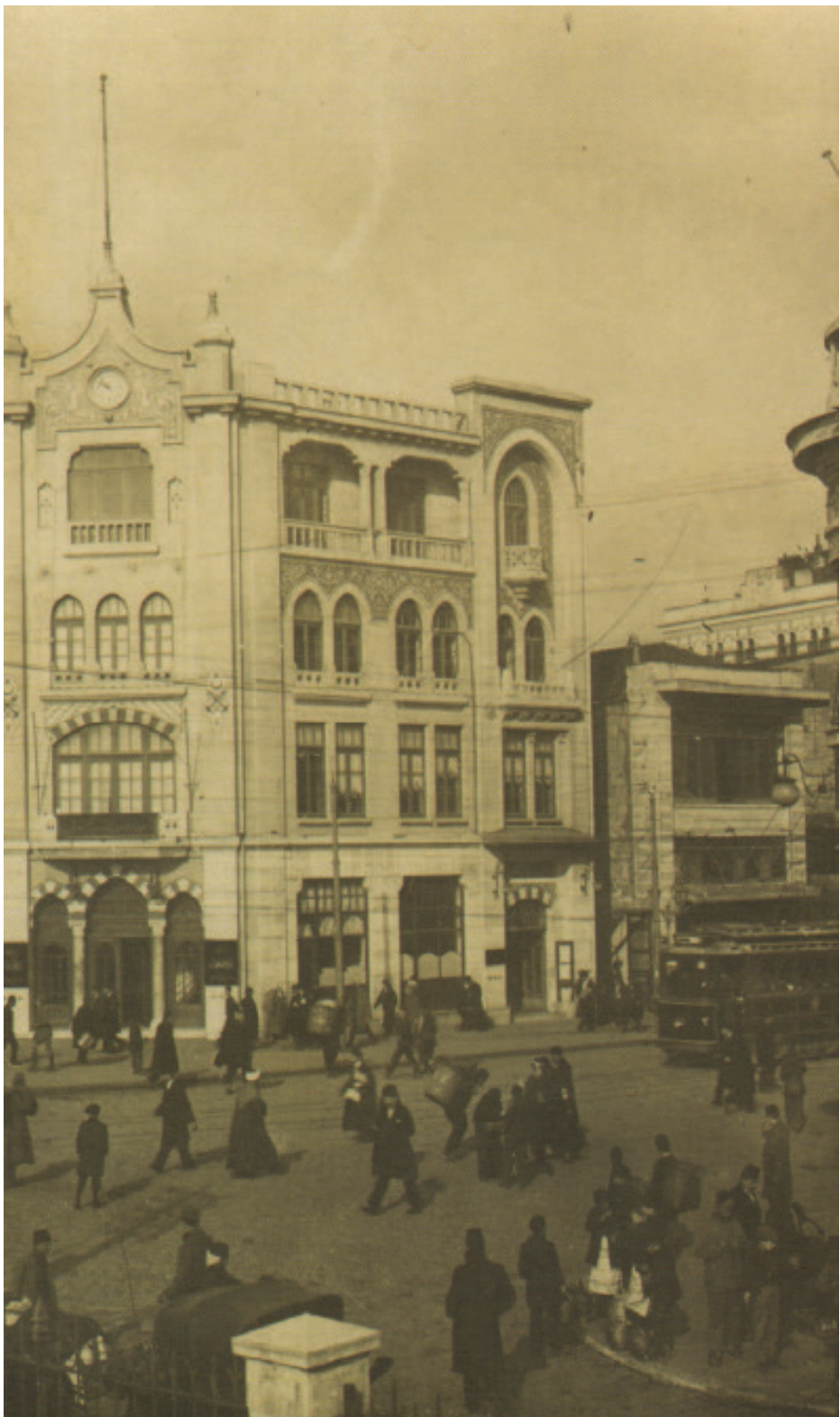

Görsel 3: Seyr-i Sefain Acentesi’nin tramvay yoluna paralel cephesi, 1928 yılı öncesi. (Nobuo Misawa, “Japon Ticaret Sergisi (1929-1937): İstanbul'daki Japon İzleri," 1453 İstanbul Kültür ve Sanat Dergisi 7, 2010, 44.) 
Günümüzde mevcut olmayan yapının mimari ve süsleme özelliklerine ilişkin bilgiler, ancak yapıya ait fotoğraflar aracılığıyla tespit edilebilmektedir. Çeşitli görsel kaynaklardan yapının üç farklı cephesinin tasarım özellikleri nispeten anlaşılabilmektedir. Yapının Karaköy Meydanı'na açılan dar köşe cephesi, bir çift pilastırla sınırlandırılmış ve bir alınlıkta taçlandırılmıştı. Vedad Bey, konik öğelerle sonlanan pilastırların aynısını, acente binasından kısa süre önce tasarladığı Mesadet Hanı'nda da kullanmıştır. Her katın pencere düzeni farklı tutulmuştur. İlk iki katta alternatif renkte taşlarla oluşturulmuş -veya bu görünümü verecek biçimde boyanmış- sivri kemeler ve geniş bir basık kemer, üçüncü katta üç sivri kemer, dördüncü katta ise geniş bir Bursa kemeri göz çarpmaktadır. İlk katta bir de mermer şebekelerle çevrili balkon bulunmaktadır. Alınlık taş bezeme ile kaplı olup, fotoğraflardan yalnızca rumi motifleri seçilebilmektedir. Bu özellikleri ile dar giriş cephesi, Yıldırım Yavuz’un tespit ettiği Milli Mimari üslubundaki yapılardaki ortak biçimlenme özelliklerini taşımaktadır. ${ }^{13}$ Yan cephede üstü bir saçak ile örtülü çıkma ile Kütahyalı Mehmed Emin Usta tarafından üretilmiş çini süslemeler ${ }^{14}$ de aynı ilkeler çerçevesinde değerlendirilebilir. Bununla beraber, yan cephelerin asimetrik tasarımı, yapıyı Yıldırım Yavuz'un belirlediği ilkelerden uzaklaştırmaktadır. Milli Mimari üslubundaki inşa edilmiş yapıların büyük bölümü simetrik cephe tasarımlarına sahipken, Vedad Bey, Mesadet Hanı'nda olduğu gibi Seyr-i Sefain Acentesi'nde de asimetrik kurguyu tercih etmiştir. Acente binası, Vedad Bey'in Valikonağı'ndaki kendi evi, ${ }^{15}$ Mesadet Hanı ve Hobyar Mescidi gibi belirli kurallar çerçevesinde kolaylıkla çözümlenemeyen bir yapı olup, Vedad Bey’in özgün yaklaşımını örneklemesi bakımından dikkat çekicidir. ${ }^{16}$

13 Yıldırım Yavuz, Milli Mimari üslubundaki yapıların ortak biçimlenme özelliklerini beş madde altında toplamıştır. Bunlar; yapıların orta doğrultulara göre simetrik biçimde planlanması ve girişlerin simetri eksenine yerleştirilmesi, yapıların sokaktan algılanan cephelerinin görkemli biçimde bezenmesi, aynı cephelerin kesme taşla kaplanması veya kesme taş izlenimi verecek biçimde sıvanıp derzlenmesi, cephelerin silmeler ile yatay yönde üç ana bölüme ayrılması ve her bölümün kendi içinde bir bütün olarak düzenlenmesi, yüzey düzenlemelerinde kullanılan öğelerin genellikle Osmanlı mimarisinin 15. ve 16. yüzyıl örneklerinden seçilmesi olarak özetlenebilir. Yavuz, Mimar A. Kemalettin, 124-125.

14 Hakan Arlı, "Kütahyalı Mehmed Emin Usta ve Eserlerinin Üslubu” (Yüksek Lisans Tezi, İstanbul Üniversitesi, 1989), 19.

15 Süha Özkan ve Nihat Tek, Vedad Bey’in çalışma biçiminin özgün çözümler üretmeye yönelik olduğunu, Vedad Bey’in mimarlı kalanında seri üretimi en çok kabul edilebilecek öğelerde bile tekil özgün üretimi yeğlediğini vurgularlar. Süha Özkan, A. Nihad Vedad Tek, "Mimar M. Vedad Bey Konağı," O.D.T.Ü. Mimarlık Fakültesi Dergisi 5, 2 (1979), 181-82.

16 Vedad Bey’in mimari yaklaşımının çeşitliliğini vurgulayan bir metin için bkz. Afife Batur, "Son Olmaması Özlenen Bir Sonsöz," M. Vedad Tek Kimliğinin İzinde Bir Mimar içinde, ed. Afife Batur (İstanbul: Yapı Kredi Yayınları, 2003), 315-319. 


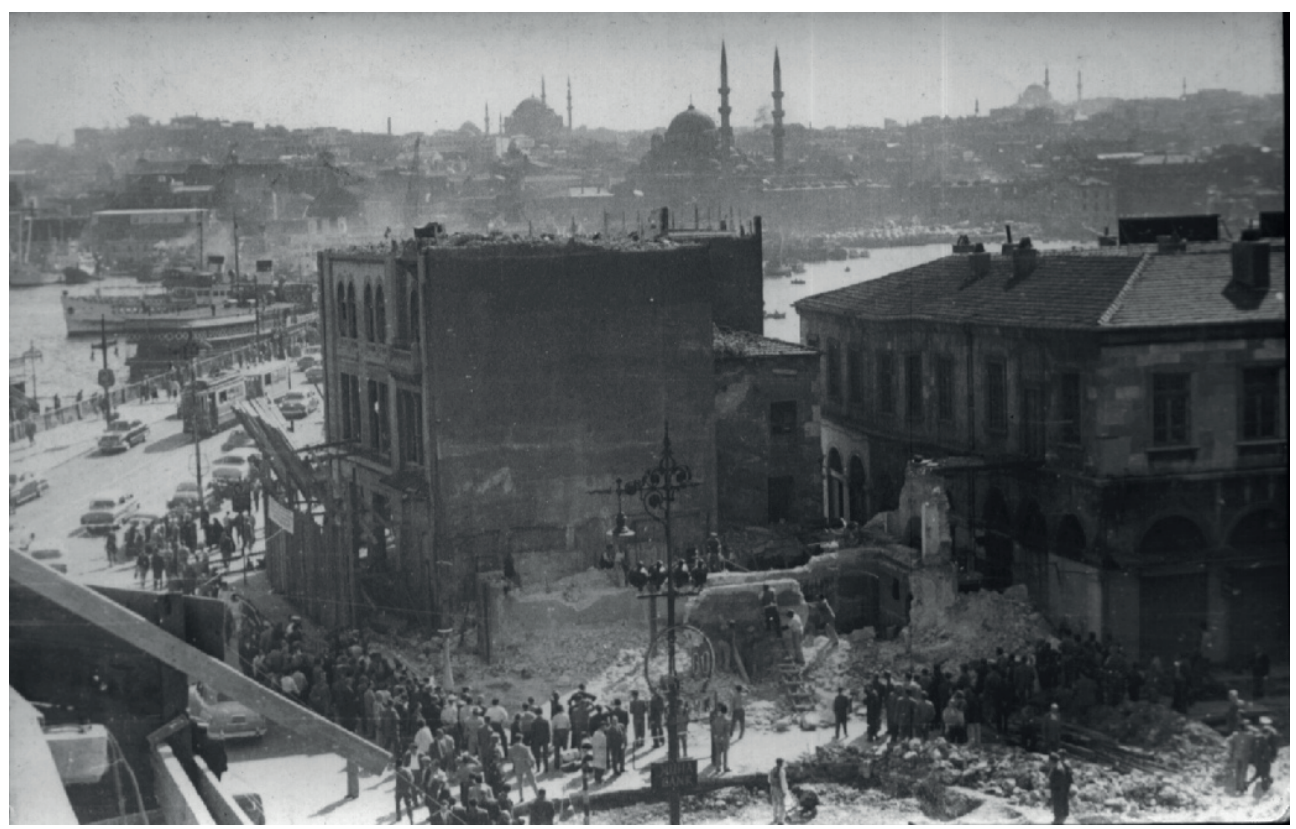

Görsel 4: Seyr-i Sefain Acentesi’nin yıkılışı, arka cepheden görünüm. (SALT Araştırma)

\section{Haydarpaşa İskelesi}

Haydarpaşa Garı'nın önünde bulunan Haydarpaşa İskelesi, çini kitabesine göre 191518 (1334) yıllarına tarihlenmektedir. ${ }^{17}$ Afife Batur, iskelenin yüksek olasılıkla bir inşa projesi olmadığını; aynı plan şeması, kitle ve hacim ölçülerine sahip eski iskele binasının dönüştürülmesiyle oluşturulduğunu öne sürmüştür. Bu argümana göre, eski iskele binasının plan ve beden duvarları büyük ölçüde korunmuş, üst yapıda yer alan soğan kubbe, deniz cephesindeki kemerler ve saçaklar ise kaldırılmıştır; yapı geniş saçaklı bir kırma çatı ile örtülmüştür. ${ }^{18}$

Haydarpaşa İskelesi'nin yoğun taş ve çini bezeme programı, pek çok tarihsel referans barındırmaktadır. Milli Mimari üslubundaki yapıların pek çoğunun süsleme programları erken ve klasik dönem Osmanlı mimarisinden ilham almıştır, fakat bu ilham her zaman doğrudan belirli bir yapıyı "alıntılamak" biçiminde tezahür etmemiştir. Örneğin, kara tarafındaki giriş cephesinin iki yanında, içi çini panolarla süslü tek sıra mukarnaslı giriş kapıları bulunur. Vedad Bey’in 1914'te projelendirdiği Tayyare Şehitleri Abidesi'nin kaidesinde de kullanmış olduğu bu öğenin anıtsal bir örneği, Kılıç Ali Paşa Camii girişinde yer almaktadır. Mukarnaslı yaşmağın iki yanındaki rumi ve palmet motifli taş bezemeler ise, Bursa Yeşil Camii’nin giriş kapısını anımsatmaktadır.

17 Kitabe tarihinin Hicri takvime göre mi Rumi takvime göre mi yazıldığı bilinmediğinden, inşa tarihi olarak iki olasılığ1 da kapsayacak biçimde 1915-18 yılları verilmiştir. Hakan Arlı, "Amel-i Mehmed Emin min telamiz-i Mehmed Hilmi Kütahya sene 1334” yazılı kitabenin 1987 yılında yapılan onarım kapsamında kaldrıldığını belirtmiştir. Arlı, "Kütahyalı Mehmed Emin," 63. 


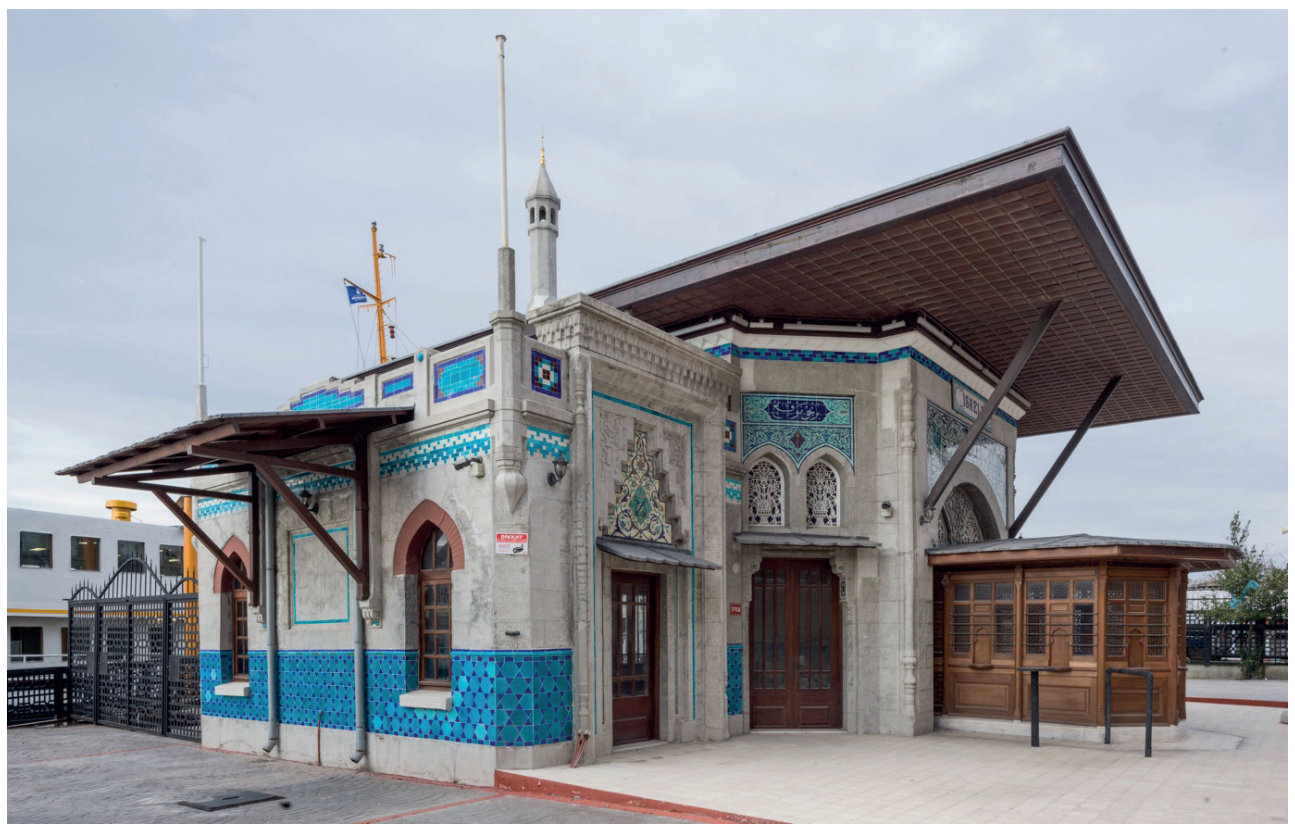

Görsel 5: Haydarpaşa İskelesi, 2005. (Cemal Emden)

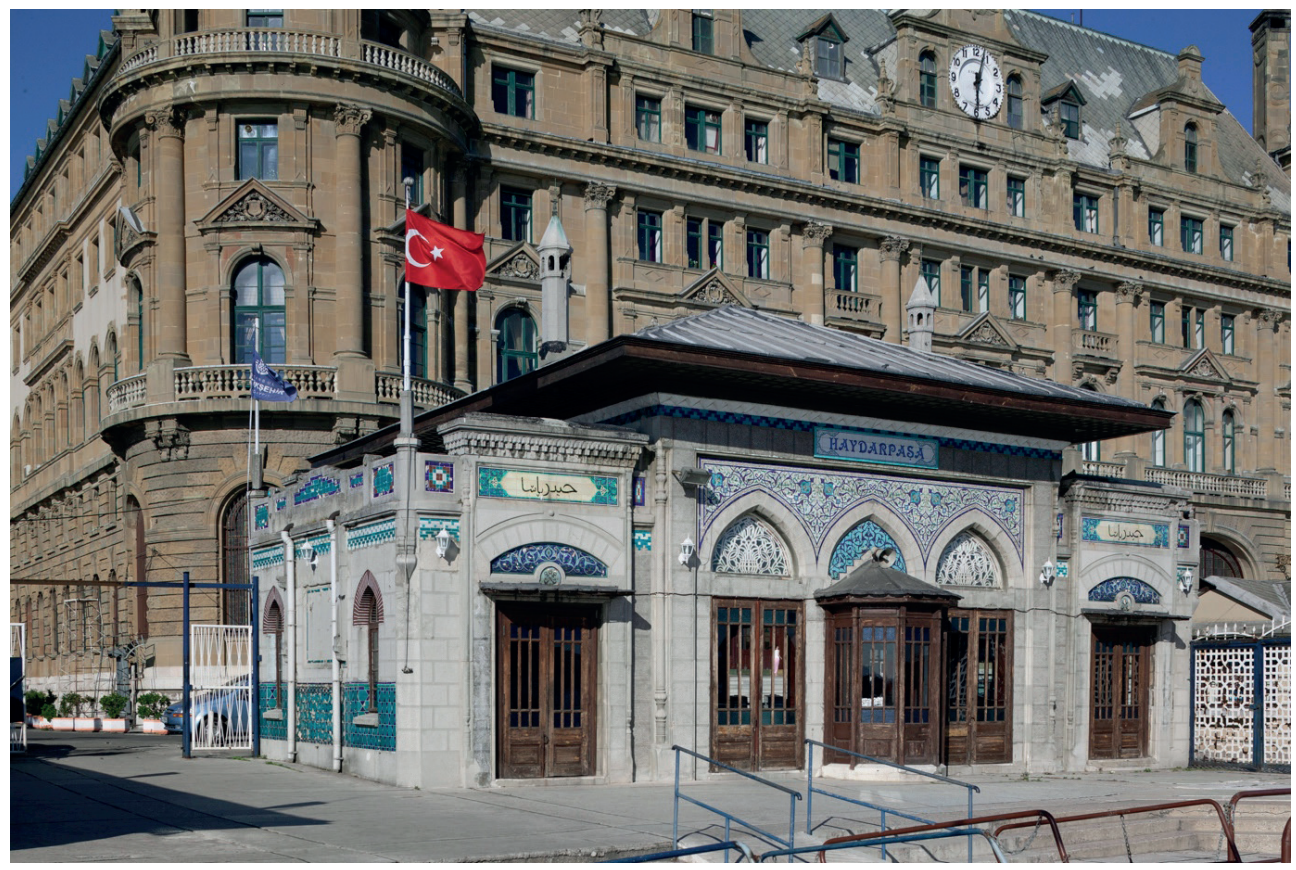

Görsel 6: Haydarpaşa İskelesi’nin deniz yönünden görünümü, 2005. (Cemal Emden) 
Yapının hem deniz cephesinde, hem de kara cephesinde yoğun çini süsleme görülmektedir. Kara cephesinde, gişelerin iki yanına yerleştirilmiş ince uzun dikdörtgen panolarda yer alan sevi motifleri özellikle dikkat çekicidir. İskelenin yan cepheleri ise, firuze renkli altıgen ve lacivert renkli üçgenlerin oluşturduğu çini süslemelerin en tanınmış örneklerinden biri ise Bursa Yeşil Camii’nde bulunmaktadır. Seyr-i Sefain Acentesi gibi Haydarpaşa İskelesi’nin çinilerini de Kütahyalı Mehmed Emin Usta gerçekleştirmiştir; günümüzde mevcut olmayan çini kitabede, kendisinin imzası da bulunmaktaydı. ${ }^{19}$

Yapının içerisindeki duvar yüzeyleri, yaklaşık bir metre yüksekliğe firuze ve lacivert renkli sırlı çini karolarla kaplanmıştır. Giriş kapısının üzerindeki sivri kemerli pencereler vitraylarla, tavanlar ise klasik dönem esinli kalemişi bezemelerle süslenmiştir.

Milli Mimari üslubundaki yapıların pek çoğunda görülen ortak özelliklerden biri, yapıların giriş cephelerinde yoğun bezeme kullanılması; arka ve yan cephelerin daha sade bırakılmasıdır. ${ }^{20}$ İskele binalarının ise, hem deniz hem de kara cepheleri bir tür giriş cephesi niteliği taşır. $\mathrm{Bu}$ sebeple, iskele binalarının tüm -veya deniz ile kara- cephelerinde, dönemin diğer yapılarından farklı olarak, yoğun süsleme kullanılabilmektedir. Bu yapıların ticaret veya nezaret yapılarından çok daha küçük ölçekli olmaları, yoğun süsleme uygulamalarını maddi açıdan da mümkün kılmış olmalıdır.

Nihat Tek, Haydarpaşa İskelesi’nin 1977 yılındaki durumunu aktarırken, “biblo gibi olan binanız, zaman zaman zevksiz kişilerin gadrine uğrayarak kuşa çevrilmiştir" ifadesini kullanmıştır. ${ }^{21}$ Yapının geçirdiği müdahalelerin kapsamını tam olarak ortaya koymak mümkün olmasa da, Nihat Tek'in anlatısına göre deniz cephesinde sağ ve sol tarafta kalan ahşap saçakların özgün halleri "fevkalade işli” olup, söz konusu saçaklar gelişigüzel biçimde ortadan kaldırılmıştır. 1977 öncesinde gerçekleştirilen bir başka müdahale ise, deniz cephesinde, vapurları gözlemekle görevli memurlar için yapılmış üçgen biçimli ve çini süslemeli mekânın yıkılması olmuştur. ${ }^{22}$

\section{Moda İskelesi}

Moda İskelesi’nin 1335 tarihli kitabesi, yapının 1916-19 yıllarında inşa edildiğini göstermektedir. ${ }^{23}$ Yapı ilk başta tek katlı ve pergolalı teraslı olarak inşa edilmiştir. İskelenin üst yapısı yıllar içinde kırma bir çatı ile kapatılmış, sonra tekrar açılmıştır. İlk değişikliğin Vedad Bey tarafindan yapıldığ 1 düşünülmektedir. ${ }^{24}$

19 Arlı, "Kütahyalı Mehmed Emin," 63.

20 Yavuz, Mimar A. Kemalettin, 124-125.

21 Nihat Tek'in 7 Kasım 1977 tarihli dilekçesinden aktaran Tülin Onur, "Mimar Vedad Tek: Mimari Kişiliği ve Dönemin Mimarlık Sorunları” (Doktora tezi, Ankara Üniversitesi, 1988), 108.

22 Nihat Tek'in 26.12.1977 tarihli dilekçesinden aktaran Onur, "Mimar Vedad Tek," 108-109.

23 Kitabe tarihinin Hicri takvime göre mi Rumi takvime göre mi yazıldığı bilinmediğinden, inşa tarihi olarak iki olasılığı da kapsayacak biçimde 1916-19 yıları verilmiştir.

24 Batur, "Kimliğinin İzinde II," 158. 


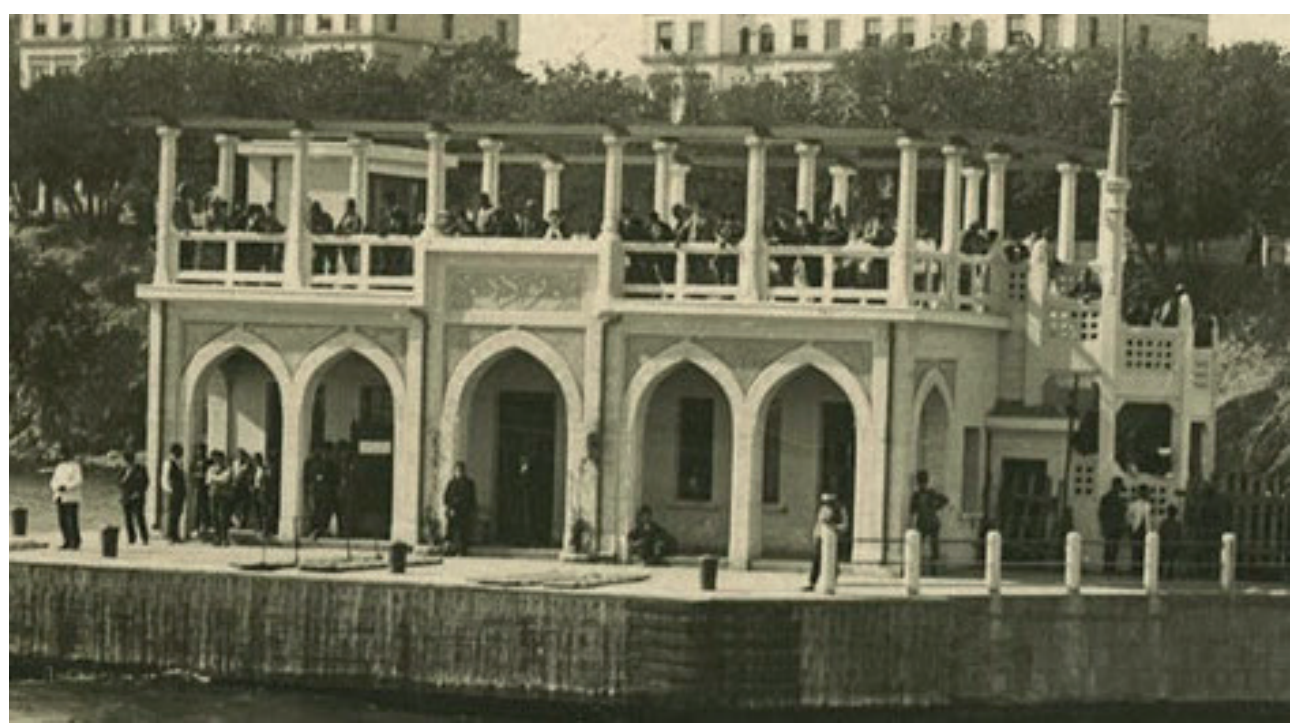

Görsel 7: Moda İskelesi, 1925 (şapka devrimi) öncesi.

(İBB Atatürk Kitaplığı kartpostal arşivi)

İskelenin 1925 öncesine tarihlenen bir fotoğrafinda, terastaki sütun dizilerinin ve odanın orijinal hali ile terasın kalabalık bir yolcu grubu tarafindan bekleme/seyir alanı olarak kullanıldığı görülmektedir.

Afife Batur, Moda İskelesi'nin dört cephesinin de farklı biçimde tasarlandığına özellikle dikkat çekerek, yapının bu yaklaşımın tek örneği olduğunu belirtmiştir. ${ }^{25}$ Yapı kitabesinin bulunduğu güney cephesi, beş sivri kemer ile simetrik biçimde düzenlenmişken, kuzey cephesinde üç tane Bursa kemerli kapı bulunmaktadır. Kuzey cephesinin iki ucunda, bilet satışının sağlandığı sivri kemerli birer pencere bulunur. Doğu cephesine, terasa çıkışı sağlayan döner merdiven; batı cephesine ise kemerli çıkma üzerine yerleştirilmiş oda hâkimdir.

Haydarpaşa İskelesi’ne kıyasla Moda İskelesi, mimari süsleme açısından çok daha sadedir. Haydarpaşa İskelesi'ndeki yoğun çini süslemenin aksine, Moda İskelesi'nde yalnızca pencere alınlıklarında çini süsleme kullanılmıştır. Özgün çini panolar 1986 yılında gerçekleştirilen restorasyonda sökülüp yerlerine düz renkli karolar yerleştirilmiştir. ${ }^{26}$ Yine Haydarpaşa İskelesi'nin diş cephesinde görülen mukarnaslı silmeler ve rumi-palmet motiflerinden oluşan taş bezemeler, Moda İskelesi'nde yer almaz.

Nihat Tek, Haydarpaşa ve Moda iskelelerinin tüm demir, ahşap ve gişe aksamının İstanbul Ahırkapı'daki Harbiye Nezareti atölyelerinde, dönemin en kalifiye ustalarına yaptırıldığını belirtmiştir. ${ }^{27} \mathrm{Bu}$ tanıklık, Vedad Bey'in projelerini gerçekleştirilirken, Harbiye Nezareti'nin kendi iç imkân ve elemanlarından faydalandığına işaret eder.

25 Batur, "Kimliğinin İzinde II," 160.

26 Arlı, "Kütahyalı Mehmed Emin," 140, 170.

27 Nihat Tek'in 26.12.1977 tarihli dilekçesinden aktaran Onur, "Mimar Vedad Tek," 108-109. 


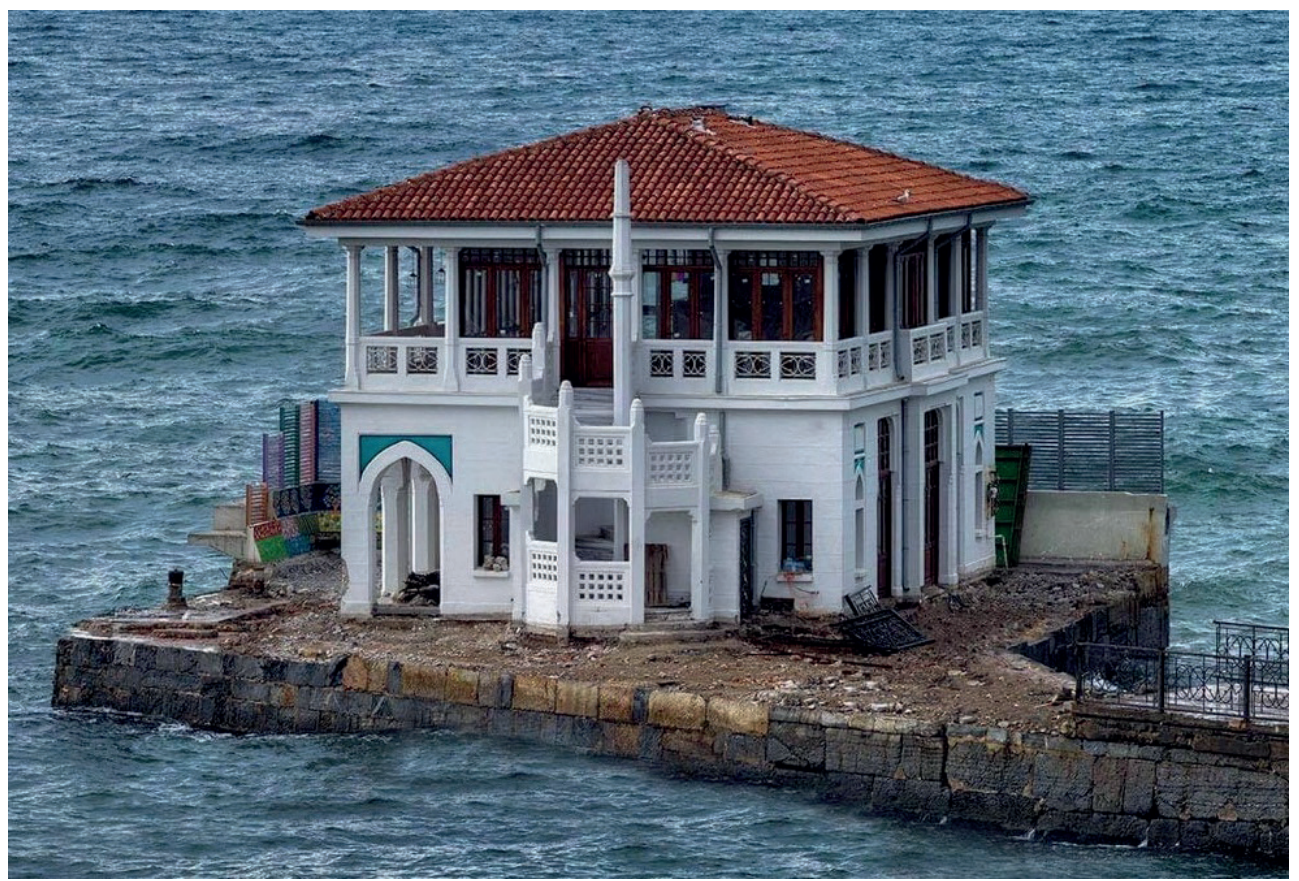

Görsel 8: Moda İskelesi, doğu cephesinden görünüm. (Cemal Emden, 2019)

\section{Kadıköy İskelesi}

Haydarpaşa ve Moda İskelelerine ek olarak, Vedad Bey Kadıköy’de inşa edilmek üzere de bir iskele projesi hazırlamıştır. Uygulanmamış olan bu projeye ilişkin elimizde yalnızca bir görsel veri bulunmaktadır. ${ }^{28}$ Çizimde görüldüğü kadarıyla iki katlı olarak düzenlenmiş öneri projesi, geniş saçaklarla çevrelenmiş bir kırma çatı ile örtülüdür. Vedad Bey, Haydarpaşa ve Moda iskelelerinden farklı olarak, Kadıköy İskelesi'nin üst yapısında bir kubbe ve bir kule de kullanmıştır. Cephelerden birinin simetrik, ötekinin ise asimetrik biçimde düzenlenmiştir. İki cephe de çini panolarla süslü basık ve sivri kemerler göze çarpmakta, yapının ikinci katında geniş bir seyir mekânının yer alacağı anlaşılmaktadır.

28 Özkan, "Reddedilen Bir Mimar," 27. 


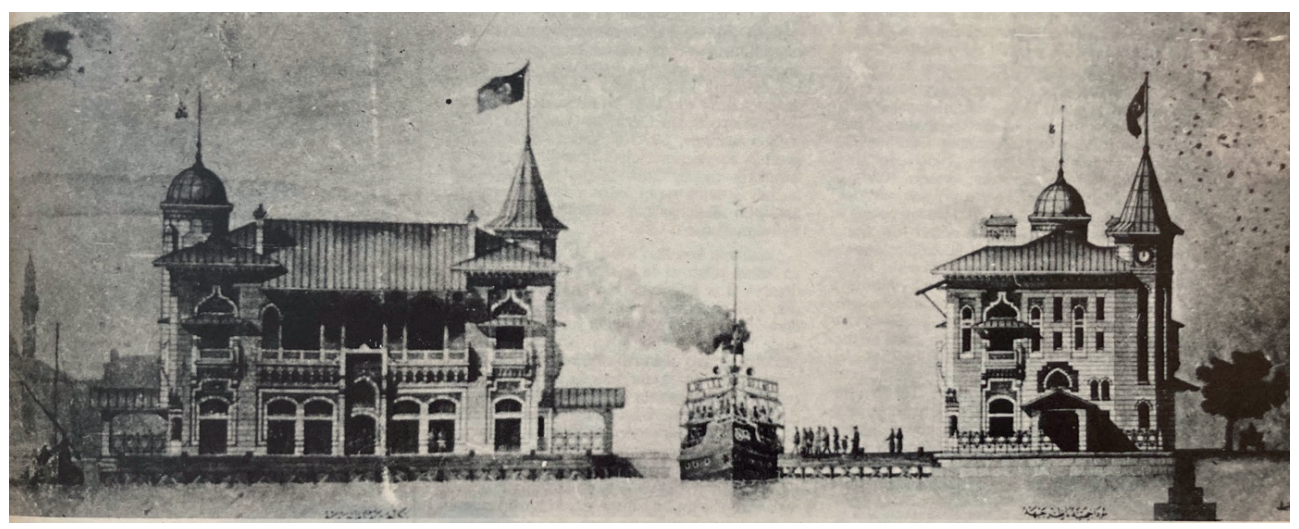

Görsel 9: Kadıköy İskelesi projesi. (Özkan, “Reddedilen Bir Mimar,” 27.)

\section{B. Üçüncü Sınıf İstasyon Binası Projesi}

Vedad Bey'in Harbiye Nezareti için çalıştığı dönemde hazırladığı bir başka proje, demir yollarına ait üçüncü sınıf istasyon binasıdır. Vedad Bey üzerine yayınlarda yer almayan bu proje, Eylül 1915-Şubat 1916 yılları arasına tarihlenir. Çizimlerden bir tanesinin arkasına "Ankara-Erzurum" notu düşülmüş olması, ${ }^{29}$ istasyonların söz konusu şehirler arasına inşa edilmesinin planlandığına işaret etmektedir. Kemâleddin Bey’in bu araştırma kapsamında tespit edilen 1915 tarihli Ankara-Sivas arası için istasyon projesi de ${ }^{30}$ söz konusu hat için istasyon inşa edilme hazırlıklarını yansıtmaktadır.

29 Vedad Bey'in istasyona ilişkin çizimlerinden arkasında Ankara-Erzurum notu düşülmüş olanı BOA. PLK.p.5490 kayıt numarasına sahiptir.

30 Kemaleddin Bey’in imzasını taşıyan proje. Cumhurbaşkanlığı Devlet Arşivleri, Osmanlı Arşivi (BOA), PLK.p.03154, 2 Mayıs 1331 (11 Haziran 1915). 


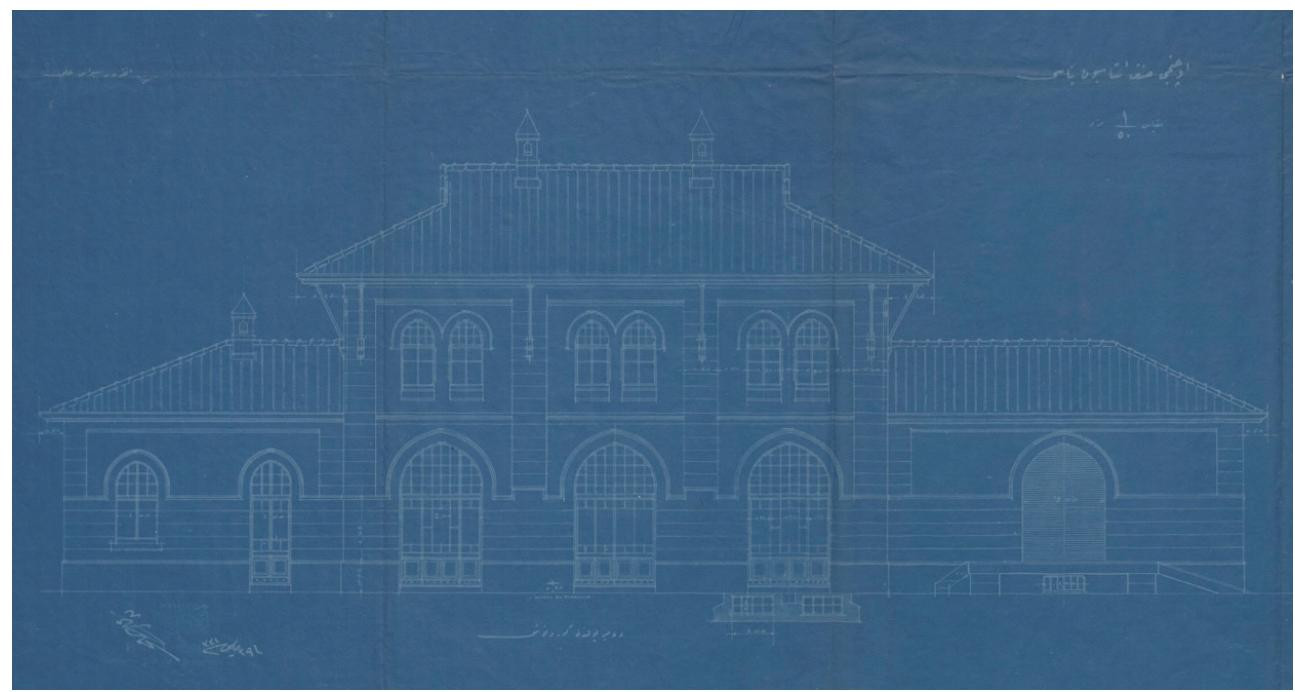

Görsel 10: “Üçüncü Sınıf İstasyon Binası” başlıklı, Kemâleddin imzalı ve 2 Mayıs 1331 (11 Haziran 1915) tarihli çizim. Sol üst köşede "Ankara-Sivas" ifadesi bulunmaktadır.

(BOA.PLK.p.03154)

Birinci Dünya Savaşı sırasında, doğudaki topraklarında demiryolu ağının olmaması sebebiyle, Osmanlı Devleti'nin bölgeye asker ve ikmal sevkiyatında büyük sorunlar yaşadığı bilinmektedir. Savaş öncesinde Haydarpaşa-Eskişehir hattı Konya'ya ulaşılabilmekteydi fakat Ankara-Erzurum hattının inşasına henüz başlanmamıştı. Savaş ile birlikte, savunma amaçlı olarak Ankara demiryolunun Sivas'a yönlendirilmesine karar verilmiş, bu görevi ise Harbiye Nezareti üstlenmiştir. Hattın inşasına, asker bir kumandan ve emrindeki mühendis mektebi öğrencilerinden oluşan yedek subaylarla, Ankara'da fiilen başlanmıştır. Mondros Mütarekesi'ne kadar bu şekilde çalışılmış, bu süreçte Ankara' dan İzzettin'e (Kırklareli) kadar 127 kilometrelik bir dekovil hattı kullanıma açılmıştır. ${ }^{31}$ Vedad Bey ve Kemaleddin Bey’e sipariş edilen Ankara-Erzurum/Sivas arasına inşa edilecek istasyon binaları, söz konusu proje kapsamında hazırlanmış olmalıdır.

31 Bu hattın açılışı 1 Ağustos 1919'de gerçekleşmiştir. Ankara-Sivas hattı ise, erken Cumhuriyet döneminde öncelikli olarak ele alınmış ve hattın tamamı 30 Ağustos 1930'da açılmıştır. Yavuz Haykır, “Atatürk Dönemi Kara ve Demiryolu İnşa Çalışmaları” (Doktora tezi, Fırat Üniversitesi, 2011), 227-29, 242. 


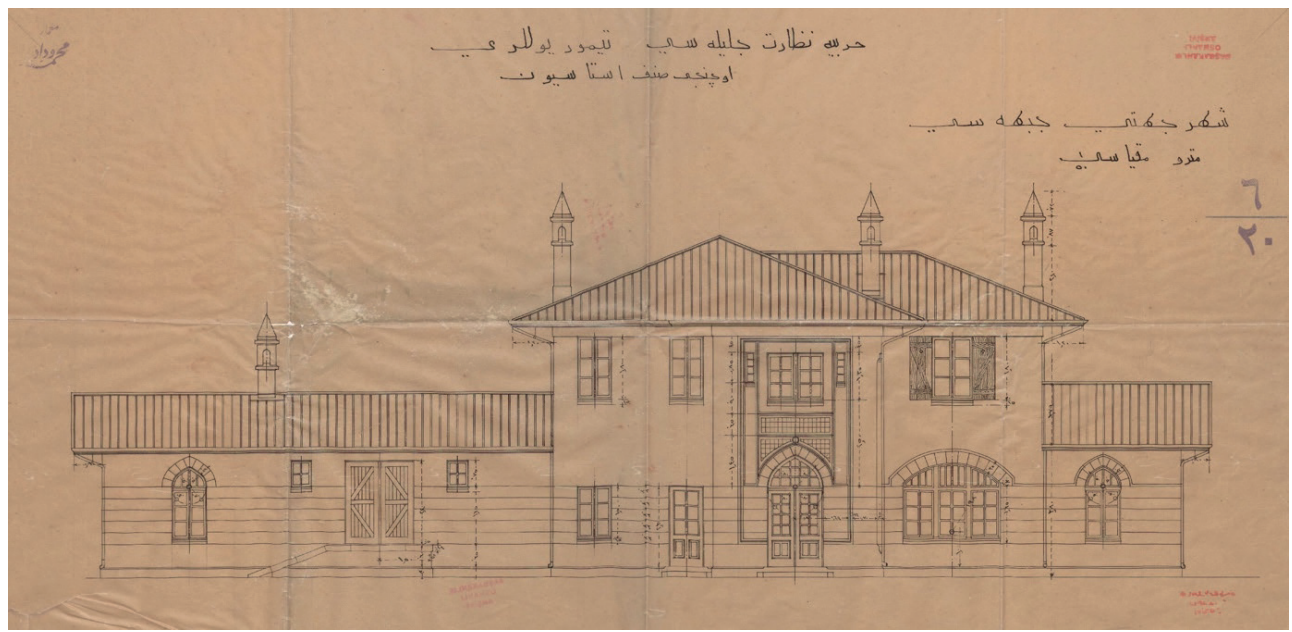

Görsel 11: "Harbiye Nezaret-i Celilesi Demiryolları Üçüncü Sınıf İstasyon" ve "Şehir ciheti cephesi” başlıklı, 6/ 20 numaralı çizim. Sol üstte Mimar Mehmed Vedad damgalı, tarihsiz. (BOA.PLK.p.03439)

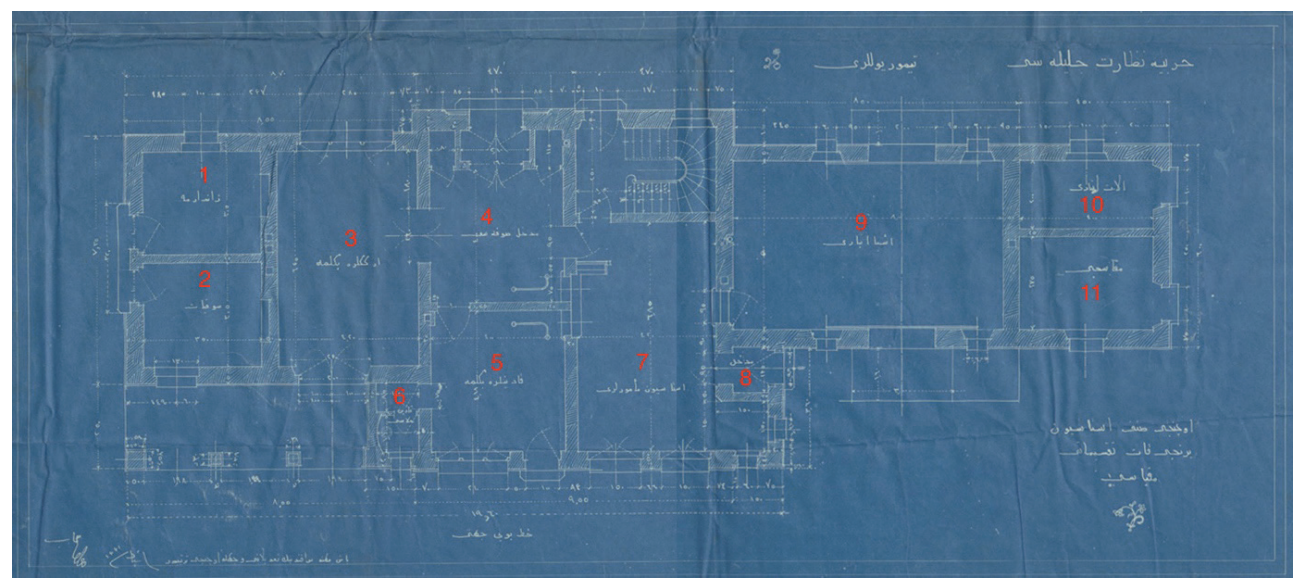

Görsel 12: "Harbiye Nezaret-i Celilesi Demiryolları Üçüncü Sınıf İstasyon Zemin Katı Taksimâtı" başlıklı, 2/9 numaralı çizim. Sol alta "Baş mühendis efendinin tadilâtı veçhiyle üçüncü tertiptir" notu düşülmüş. Şubat 1331 (Şubat-Mart 1916) tarihli ve mimar Vedad imzalı. (BOA.PLK.p.05105) (1-Jandarma odas1, 2-Sevkiyat, 3-Erkeklere bekleme, 4- Medhal sofası, 5- Kadınlara bekleme, 6- Kadın helası, 7- İstasyon memurları, 8-Medhâl, 9- Eşya ambarı, 10- Alet ambarı, 11- Makasçı) 


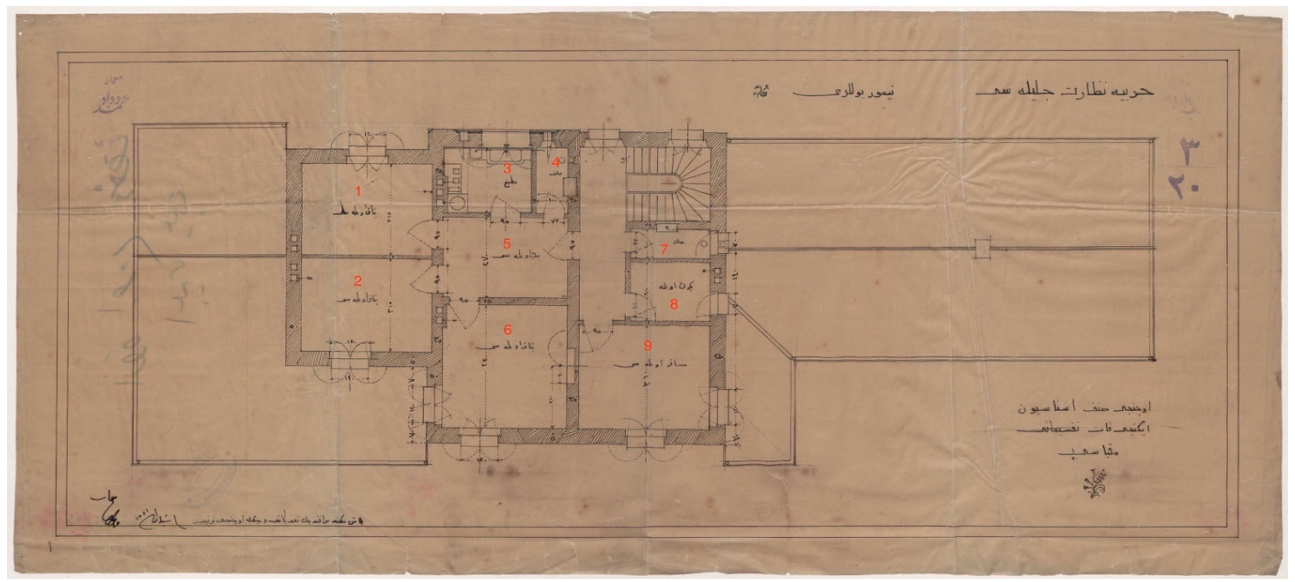

Görsel 13: "Harbiye Nezaret-i Celilesi Demiryolları Üçüncü Sınıf İstasyon İkinci Kat Taksimâtı" başlıklı, 3/20 numaralı çizim. Sol alta "Baş mühendis efendinin tadilâtı veçhiyle üçüncü tertiptir" notu düşülmüş. Şubat 1331 (Şubat-Mart 1916) tarihli ve mimar Vedad imzal1. (BOA.PLK.p.03045) (1- Yatak odas1, 2- Yatak odas1, 3- Matbah, 4- Hela, 5- Yemek odas1, 6- Yatak odas1, 7- Hela, 8- Küçük oda, 9- Misafir odas1.)

İstasyon binasına ilişkin en kapsamlı görsel verileri, "Şehir ciheti cephesi," "Zemin kat taksimâtı" ve "İkinci kat taksimâtı" başlıklı çizimler barındırmaktadır. Bunlardan yola çıkarak, istasyonun iki katlı bir ana bina ve ona eklemlenen tek katlı iki birimden oluştuğu anlaşılmaktadır. İstasyon binasının uzunlamasına dikdörtgen bir plana sahip olan giriş katında; jandarma odası, sevkiyat, erkeklere bekleme, kadınlara bekleme, kadın helası, medhâl [giriş] sofası, istasyon memurları, medhâl, eşya ambarı, alet ambarı, makasçı olmak üzere on bir adet mekân tanımlanmıştır. 1916 tarihli plan ile cephe tasarımı beraber incelendiğinde, sivri kemerli ana girişin giriş sofasına açıldığı anlaşılmaktadır. Buradan erkek ve kadın bekleme salonlarına geçiş sağlanmaktadır. İlgi çekici bir nokta, kadın ve erkek bekleme odalarının birbirinden ayrı düzenlenmesi ve erkek bekleme odasının kadın bekleme odasından yaklaşık bir buçuk kat daha büyük tutulmuş olmasıdır. Erkek bekleme salonuna bitişik olan jandarma odası ile sevkiyat odasının girişleri ayrı tutulmuştur. Cephe çiziminde, ana girişin bir yanında daha küçük ölçekli bir kapı, öteki yanında ise basık kemerli geniş bir pencere görülmektedir. Basık kemerli geniş pencere erkek bekleme salonuna aittir. Küçük kapı ise, üst kata çıkışı sağlayan merdivenlere açılır. Giriş katının diğer mekânları, istasyon çalışanlarına ve depolama alanlarına ayrılmıştır.

İkinci kat için giriş katının yaklaşık olarak üçte biri oranında bir alan ayrılmıştır. Plan üzerinde tanımlanan mekânlar; üç ayrı yatak odası, yemek odası, matbah, iki tane hela, misafir odası, küçük oda biçimindedir. Yatak odaları, yemek odası ve mutfak birimleri, ilk kattan farklı olarak ikinci katın istasyon çalışanlarının barınmasına yönelik olarak planlandığını göstermektedir. 


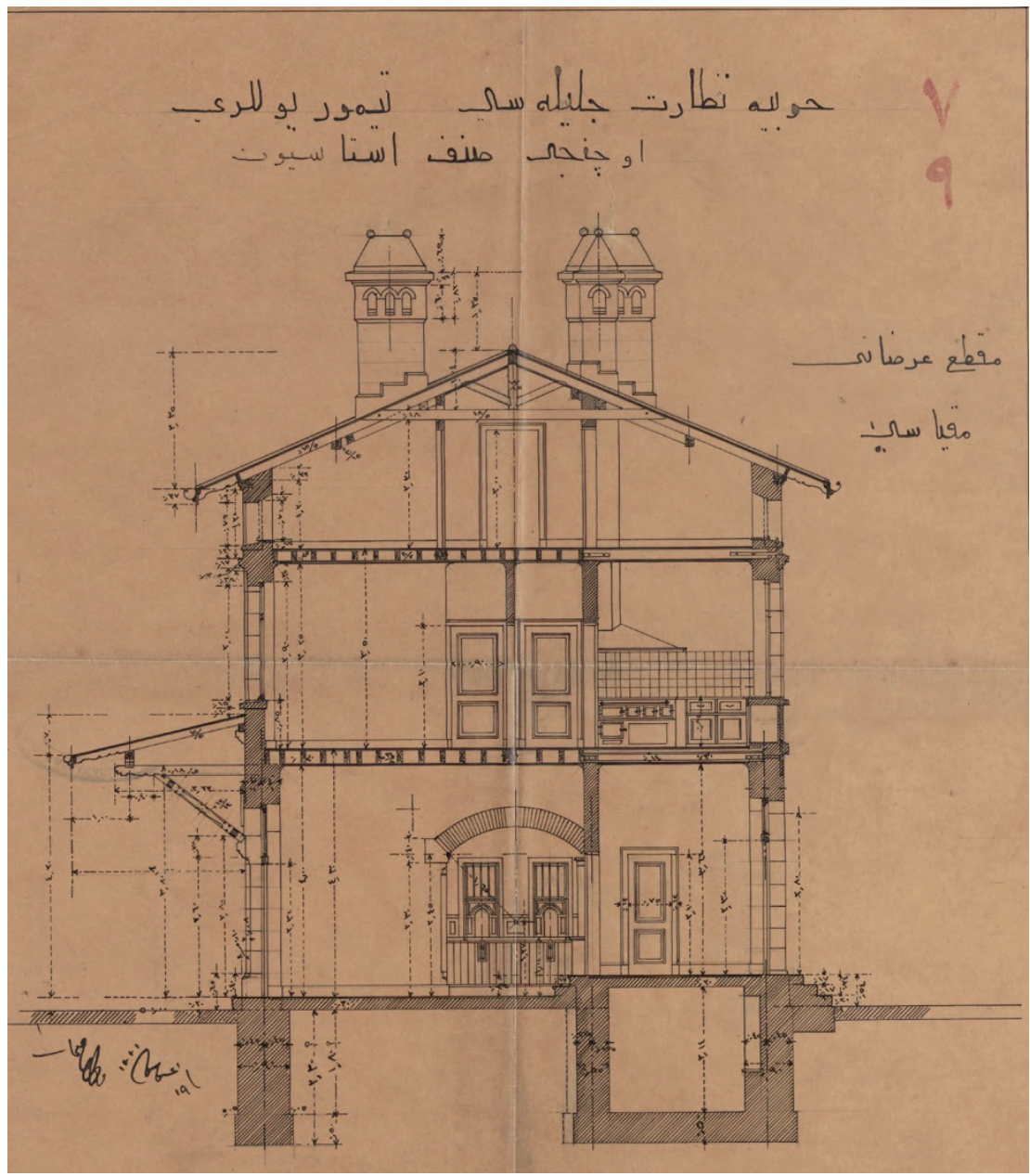

Görsel 14: "Harbiye Nezaret-i Celilesi Demiryolları Üçüncü Sınıf İstasyon” başlıklı, "Maktâ’-i arzân̂̂" notu düşülmüş, 7/9 numaralı enine kesit çizimi. 19 Ağustos 1331 (1 Eylül 1915) tarihli ve mimar Vedad imzalı. (BOA.PLK.p.03053) 
İki katlı ve kırma çatı ile örtülü yapının şehre bakan cephesi sivri kemerli bir giriş kapısına sahiptir. Kapının üstü, üst kat pencerelerine kadar, olasılıkla çini ile süslenecektir. Giriş katında sivri ve basık kemerler kullanılmış, çatı saçağı ise geniş tutulmuştur.
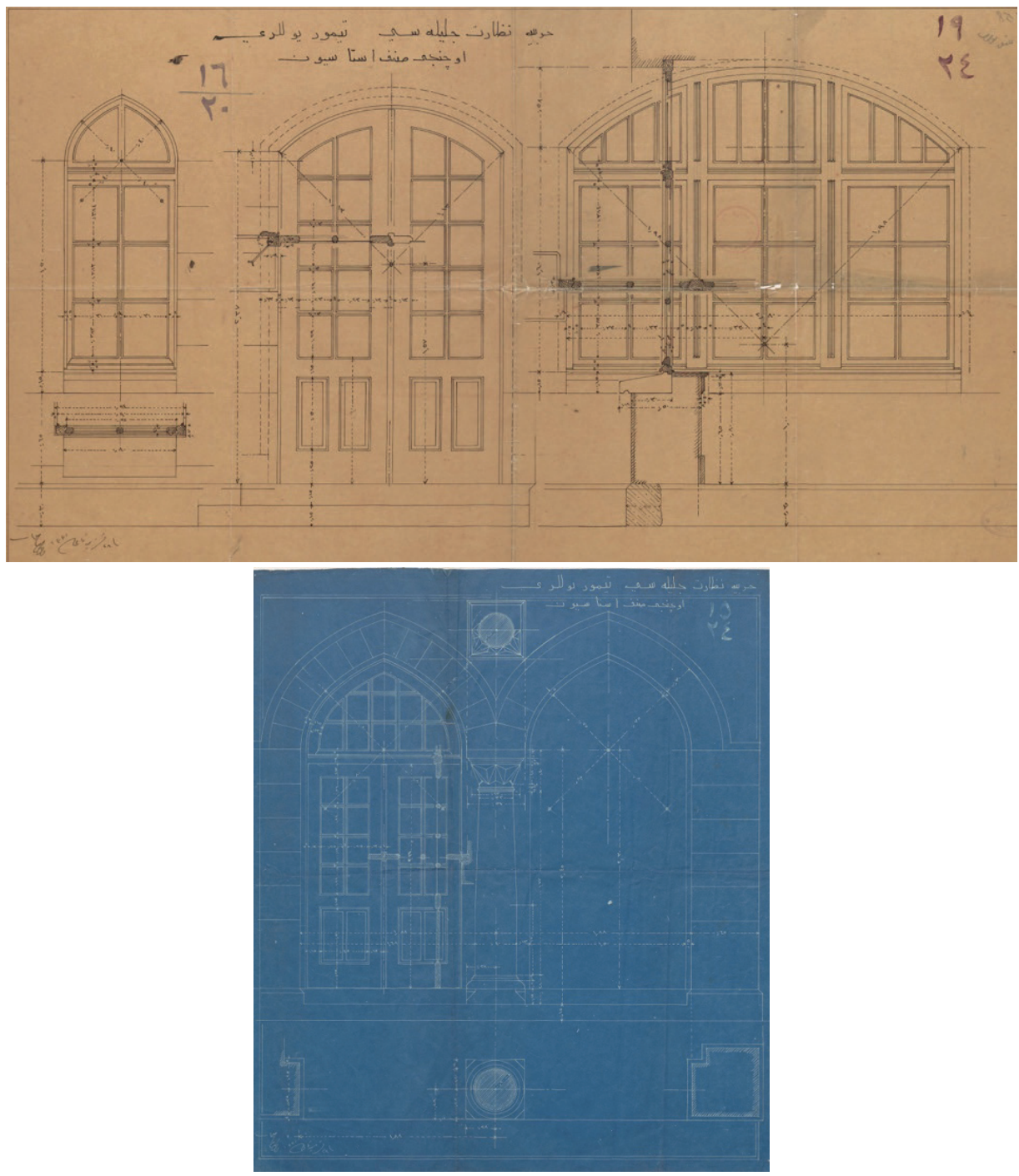

Görsel 15 (üst): “Harbiye Nezaret-i Celilesi Demiryolları Üçüncü Sınıf İstasyon” başlıklı, 19/24 numaralı kapı ve pencere detay çizimleri. 28 Teşrinisani 1331 (11 Aralık 1915) tarihli ve mimar Vedad imzalı. (BOA.PLK.p 03358)

Görsel 16 (alt): "Harbiye Nezaret-i Celilesi Demiryolları Üçüncü Sınıf İstasyon” başlıklı, 15/24 numaral1, mavi ozalit üzerine kap1, kemer ve sütun detay çizimleri. R.28 Teşrinisani 1331/11 Aralık 1915 tarihli ve mimar Vedad imzalı. (BOA.PLK.p 03187) 
Yapının farklı bir cephesine ait detay çizimde, basık kemerli bir kapı, basık kemerli geniş bir pencere ve sivri kemerli bir başka pencere görülmektedir. Yapının yine farklı bir cephesine veya iç mekânına ait bir kapı detay çiziminde, sivri kemerlerin arasındaki sütunlarda, baklavalı başlıklar yerleştirilmiştir. Vedad Bey'in "saçak detayı" ve "ocak detayı” notlarıyla hazırladığı çizimde ise, istasyonun bacalarındaki ufak sivri kemerler ve baca külahını taçlandıracak alemler göze çarpmaktadır.

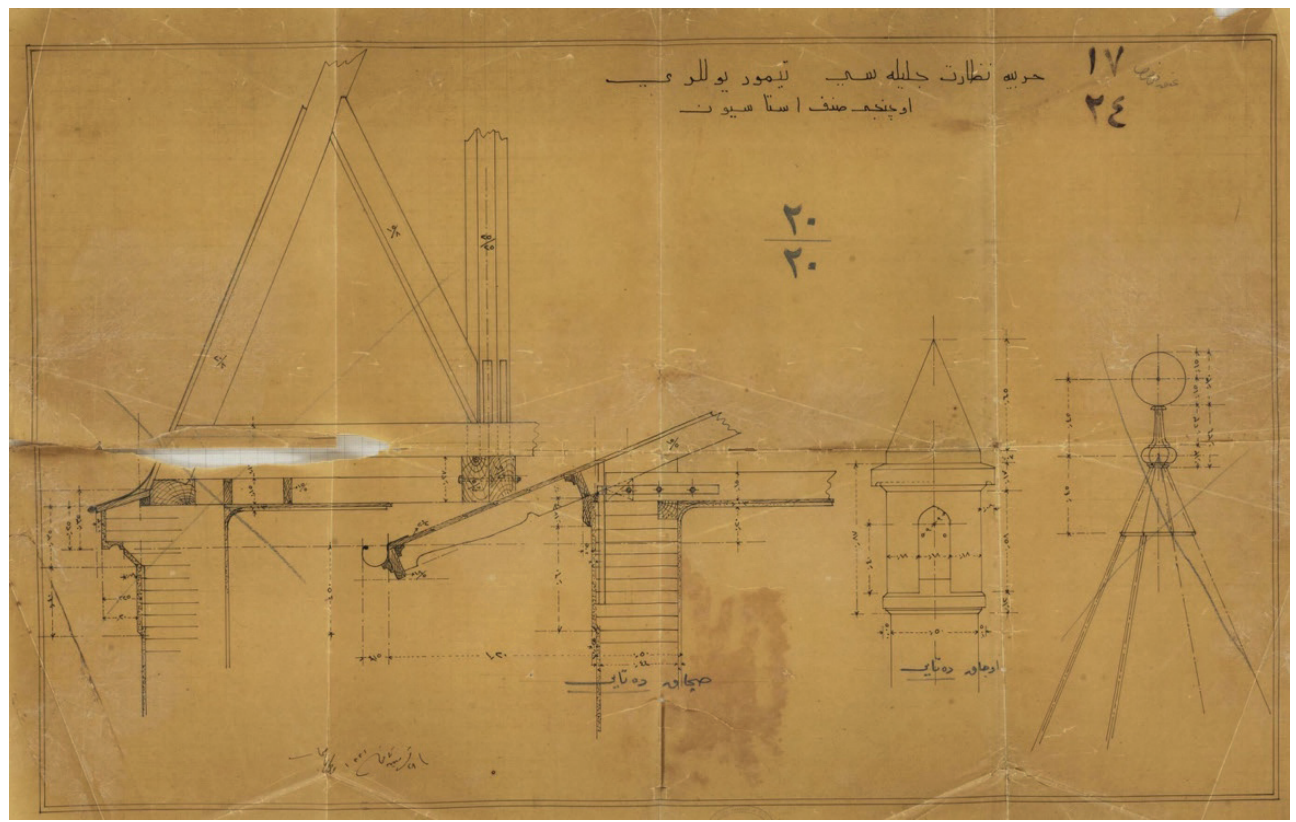

Görsel 17: "Harbiye Nezaret-i Celilesi Demiryolları Üçüncü Sınıf İstasyon” başlıklı, 17/24 numaralı "saçak detayı" ve "ocak detayı" Baca, saçak ve alem detay çizimleri. 28 Teşrinisani 1331 (15 Aralık 1915) tarihli ve mimar Vedad imzalı. (BOA.PLK.p.03053)

Yukarıda incelenen veriler, istasyon binasının Milli Mimari üslubunun sade ve olağan bir örneği olduğunu göstermektedir. Savaş koşullarında ve asker grupları tarafindan inşa edilecek bir yapı olan istasyon binası, Vedad Bey'in Seyr-i Sefain İdaresi için hazırladıklarına kıyasla, olabildiğince sade tasarım özellikleri taşımaktadır. Bu durum, işlevselliğin ön planda tutulduğu ve tip proje biçiminde uygulanması düşünülerek hazırlanmış bir proje izlenimi yaratmaktadır.

Vedad Bey’in üçüncü sınıf istasyon binası tasarımını, Mehmet Emin Başar ve Hacı Abdullah Erdoğan'ın Türkiye'deki gar binalarının gruplandırılmasına ilişkin getirdikleri öneri kapsamında, ${ }^{32}$ "giriş bölümü iki katlı, yan bölümleri tek katlı garlar” başlığı altında değerlendirmek mümkündür. Söz konusu yapı tipinin Türkiye sınırları içerisinde pek çok

32 Bu sınıflamaya göre, giriş bölümü iki katlı, yan bölümleri tek katlı garlar simetrik ve asimetrik planlılar olarak ikiye ayrılmaktadır. Vedad Bey’in tasarımı asimetrik planlı alt başlığına aittir. Mehmet Emin Başar ve Hacı Abdullah Erdoğan, “Osmanlı'dan Cumhuriyet'e Türkiye'de Tren Garları," Selçuk Üniversitesi MühendislikMimarlık Fakültesi Dergisi c.24 s.4, (2009), 40-41. 
örneği vardır; Maltepe, Gölaşi, Bostanci, Feneryolu, Kartal, Kızıltoprak garları bu tipin örneklerindendir. ${ }^{33}$ Bunlardan Kizıltoprak, Feneryolu, Bostancı ve Pendik istasyonları 1910 yılında inşa edilmiş olup, ${ }^{34}$ Vedad Bey’in projesinin öncüsü niteliğindelerdir.

Vedad Bey’in tren istasyonu projesinin değiştirilmeden uygulandığını gösteren bir istasyon örneği, bu araştırma kapsamında tespit edilmemiştir. Öte yandan, Asker Demiryolları Genel Müdürlüğü’nden Dâhiliye Nezareti’ne gönderilen 29 Temmuz 1916 tarihli bir tezkirede, Ankara-Erzurum hattı istasyon binalarının inşası için gereken tuğlaların üretiminde kullanılmak üzere iki adet tuğla makinesinin Harbiye Nezareti’nin ilgili komisyonuna teslim edilmesi talep edilmiştir. ${ }^{35} \mathrm{Bu}$ belge, istasyon binalarının inşasına en azından başladığını göstermektedir. İnşa sürecine ilişkin bir başka belge ise, Kütahyalı Mehmed Emin Usta'nın “istasyonlar için çini ürettiğini”" belirtmiş olmasıdır. ${ }^{36} 1920$ 'lerde inşa edilen tren istasyonlarında Vedad Bey'in projesinden yararlanılmış olması ihtimal dâhilindedir. Bu dönemde inşa edilen istasyonlar, benzer biçimde iki katı ıir ana mekân ve ona eklemlenen tek katlı iki mekân ile uzunlamasına dikdörtgen plana sahip olup, sivri ve basık kemeleri ve geniş saçakları ile Milli Mimari üslubuyla uyumlulardır. ${ }^{37}$

\section{Enver Paşa Köşkü}

Vedad Bey Harbiye Nezareti baş mimarı iken Enver Paşa için bir köşk inşa etmiştir. ${ }^{38}$

33 Başar ve Erdoğan, "Osmanlı'dan Cumhuriyet'e," 40.

34 Yonca Kösebay Erkan, “Anadolu Demiryolu Çevresinde Gelişen Mimari ve Korunması” (Doktora tezi, İstanbul Teknik Üniversitesi, 2007), 421.

35 BOA,DH.İ.UM.EK.17/73, 16 Temmuz 1332 (29 Temmuz 1916).

36 Arlı, "Kütahyalı Mehmed Emin,” 19. 27 Kanunuevvel 1333(27 Aralık 1917) tarihinde Kütahya Mutasarrıflı̆̆1 aracılığıyla Ticaret Nezareti'ne takdim edilen dilekçede, Mehmed Emin Usta’nın "Harbiye Nezareti namına çeşitli istasyonların cephelerinde" çini ürettiği ifadesi geçmektedir.

37 Bu yapılara örnek olarak, 1925 yılında inşa edilmiş olan Kırıkkale Tren İstasyonu ile 1930 yılı öncesinde inşa edilmiş olan Karabük Tren İstasyonu verilebilir. Söz konusu yapılara ilişkin araştırmalar için bkz. Lütfiye Göktaş Kaya, "Karabük Kent Kimliği İçinde İstasyon Binasının Yeri," XX. Uluslararası Ortaçağ ve Türk Dönemi Kazıları ve Sanat Tarihi Araştırmaları Sempozyumu Bildirileri içinde (Sakarya: 2016), 504-518. Murat Çerkez, "Kırıkkale Tren Garı Üzerine Bazı Tespitler", Troyacademy 5, 2 (2020), 231-257.

38 Özkan, "Mimar Vedat Tek," 50. İlhan Tekeli ve Selim İlkin tarafından hazırlanmış Mimar Kemâleddin'in yapı listesinde, köşkün Kemâleddin Bey tarafından tasarlandığına yönelik bir ifade bulunur. Bu listede “Ortaköy’de Sultan Hazretlerinin tepedeki büyük köşkleri (Enver Paşa Köşkü)” ifadesi yer alır ve köşkün II. Meşrutiyet öncesinde inşa ettiği belirtilir. Kaynak gösterilmediğinden dolayı bu bilgiyi teyit etmek mümkün olamamaktadır. Olasılıkla Sedat Çetintaş’ın "Mimâr Kemâlettin Mesleği ve Sanat Ülküsü” makalesinde Kemâleddin Bey’in II. Meşrutiyet'in ilanından önce inşa ettiği yapılar arasında "Ortaköy'de Sultan Hazretlerinin tepedeki büyük köşkleri”nin gösterilmesinden yola çıkılarak yapı Kemâleddin Bey’in eserleri arasına eklenmiştir. Sedat Çekintaş'ın makalesinde Enver Paşa'nın adı geçmemekle beraber, Enver Paşa ile Emine Naciye Sultan 1914 yılında evlendikleri için köşkün II. Meşrutiyet öncesine tarihlenmesi de mümkün görünmemektedir. Öte yandan yapı, Yıldırım Yavuz tarafından hazırlanan Kemaleddin Bey’in tasarladığı konutlar listesinde bulunmamaktadır. Lale Uluç ile Tülin Onur tezlerinde Enver Paşa Köşkü'nü Vedad Bey’in yapı listesine dahil etmiştir. Afife Batur, Tekeli ve İlkin'in ifadesinden dolayı Enver Paşa Köşkü'nün aidiyeti konusunda bir belirsizlik olduğunu söylemekle birlikte, köşkün Vedad Bey’in eseri olmasının hayli güçlü bir ihtimal olduğunu belirtmiştir. İlhan Tekeli ve Selim İlkin, Mimar Kemalettin 'in Yazdıkları (Ankara: Şevki Vanlı Mimarlık Vakfı Yayınları, 1997), 244. Yavuz, Mimar A. Kemalettin, 269-322, Sedat Çetintaş, "Mimâr Kemâlettin, Mesleği ve Sanat Ülküsü," Mimar Kemalettin'in Yazdıkları, der. İlhan Tekeli ve Selim İlkin (Ankara: Şevki Vanlı Vakfı Yayını, 1997), 
Süha Özkan ve Nihat Tek' in aktarımına göre, Enver Paşa'nın Vedad Bey'inValikonağı'ndaki evine olan hayranlığı, Kuruçeşme'deki kendi konağını Vedad Bey’e sipariş etmesine sebep olmuştur. ${ }^{39}$ Ortaköy sırtlarında bulunan köşkün inşası, 1915 yılında tamamlanmıştır. ${ }^{40}$ Doğrudan Harbiye Nezareti için değil, Harbiye Nazırı'nın özel konutu olarak gerçekleştirilen yapı, Harbiye Nezareti mimarlığı ile serbest mimarlığın ara kesitinde, özel konuma sahip bir iş olarak değerlendirilebilir.
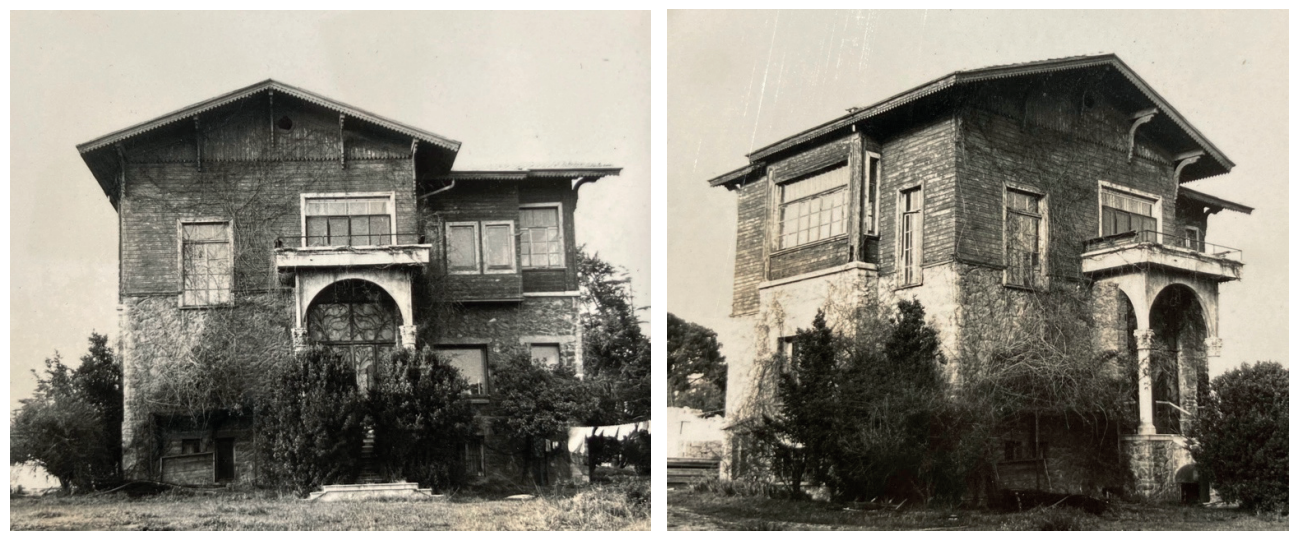

Görsel 18, 19: Enver Paşa Köşkü’nün 1980’lerdeki görünümü. (Yapının İstanbul III Numaralı Kültür Varlıklarını Koruma Kurulundaki dosyası.)

174 metrekarelik bir zemine inşa edilmiş olan Enver Paşa Köşkü, temel olarak, enlemesine dikdörtgen bir ana mekan ve ona giriş cephesinde eklemlenen daha küçük ölçekli enlemesine dikdörtgen bir zemin planına sahiptir. ${ }^{41}$ Köşkün III Numaralı Kültür Varlıklarını Koruma Kurulu'ndaki dosyasında bulunan ve 1980'lere tarihlenen fotoğrafları, yapının iki katlı, kırma çatı ile örtülü, sade görünümünü ortaya koymaktadır. Giriş cephesine, iyonik başlıklarla süslü iki sütun ve yuvarlak kemerli giriş hâkimdir. Yan cepheler çıkmalarla hareketlendirilmiştir.

Enver Paşa Köşkü’nün cephe tasarımının, II. Meşrutiyet yıllarında devlet katında desteklenmiş Milli Mimari üslubundan uzak kalması ilgi çekici bir durumdur. Köşkün cephelerinde, Vedad Bey’in bu dönemde inşa ettiği diğer yapılarda veya yine çok yakın tarihte tamamladığı kendi konutunda kullandığı sivri kemerler, Bursa kemerleri, taş bezemeler, çini panolar bulunmaz.

298. Lale Uluç, "M. Vedat Tek, Architect: An Episode in Turkish Architecture" (Yüksek lisans tezi, Boğaziçi Üniversitesi, 1987), 195. Onur, "Mimar Vedad Tek," 179. Batur, "Kimliğinin İzinde I: Sermimarlığa Doğru," M. Vedad Tek Kimliğinin İzinde Bir Mimar içinde, ed. Afife Batur (İstanbul: Yapı Kredi Yayınları, 2003), 129.

39 Özkan ve Tek, "Mimar M. Vedad Bey Konağı," 182.

40 İstanbul, Beşiktaş, Ortaköy, 21 pafta, 35 ada, 140 parselde bulunan Enver Paşa Köşkü’nün İstanbul III Numaralı Kültür Varlıklarını Koruma Kurulundaki dosyasındaki 27.2.1984 tarihli dilekçe.

41 İstanbul, Beşiktaş, Ortaköy, 21 pafta, 35 ada, 140 parselde bulunan Enver Paşa Köşkü’nün İstanbul III Numaralı Kültür Varlıklarını Koruma Kurulundaki dosyasındaki 11748 numaralı ve 18.1.1980 tarihli kurul kararının ekinde bulunan Enver Paşa Köşkü planı. 
Bu bağlamda, özellikle ana girişte kullandığı iyonik başlıklar ve yuvarlak kemer, şaşırtıcı öğeler olarak öne çıkarlar.

Ancak, iç mekândaki süslemelerde, Milli Mimari ile ilişkilendirilebilecek öğelerle karşılaşılmaktadır. Birinci katta bulunan hamam, 17. yüzyıl Osmanlı örneklerinden ilhamla hazırlanmış çini panolarla donatılmıştır. Benzerleri Hatice Turhan Valide Sultan Türbesi girişinde ve Yeni Camii Hünkâr Kasrı'nda bulunan bu panolarda, rumilerle dolgulanmış dilimli bir kemer içerisinde vazodan çıkan hatayi çiçekler yer alır. ${ }^{42}$ Panolar, olasılıkla Kütahyalı Mehmed Emin Usta tarafından hazırlanmıştır. Banyoda görülen turkuaz karoların benzerleri, Vedad Bey'in kendi evinde ve Mesadet Hanı'nda da kullanılmıştır.

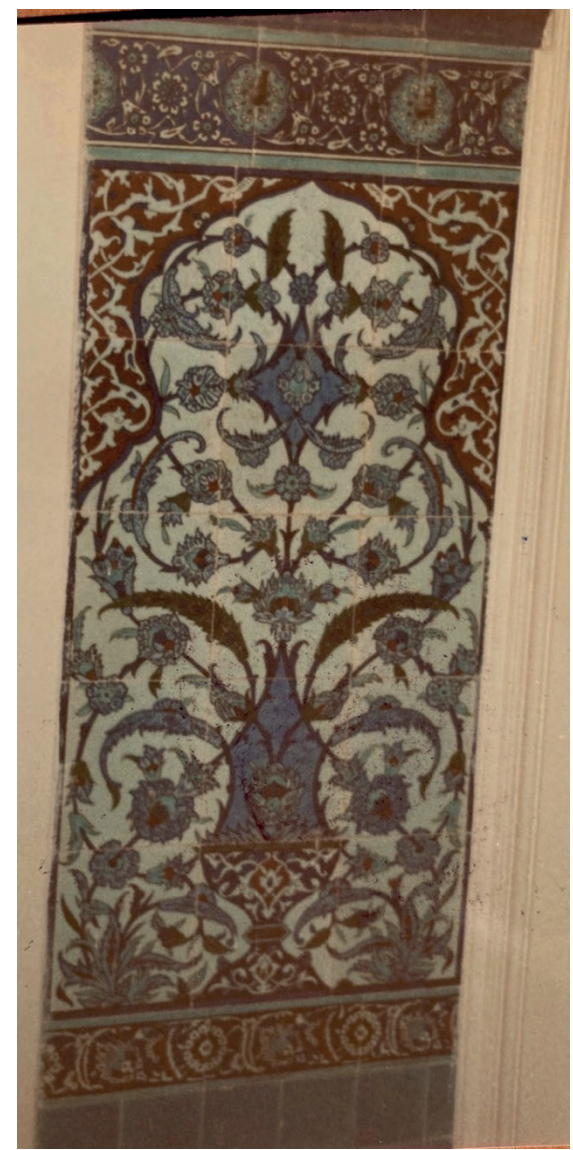

Görsel 20: Enver Paşa Köşkü hamamındaki çini panolardan biri. (Yapının İstanbul III Numaralı Kültür Varlıklarını Koruma Kurulundaki dosyası.)

42 Emel Emine Dönmez, “Türk Çini Sanatının Sürekliliği İçinde XVII. Yüzyıl Eserlerinin Yeri” (Doktora Tezi, İstanbul Üniversitesi, 2001), 92-95. 


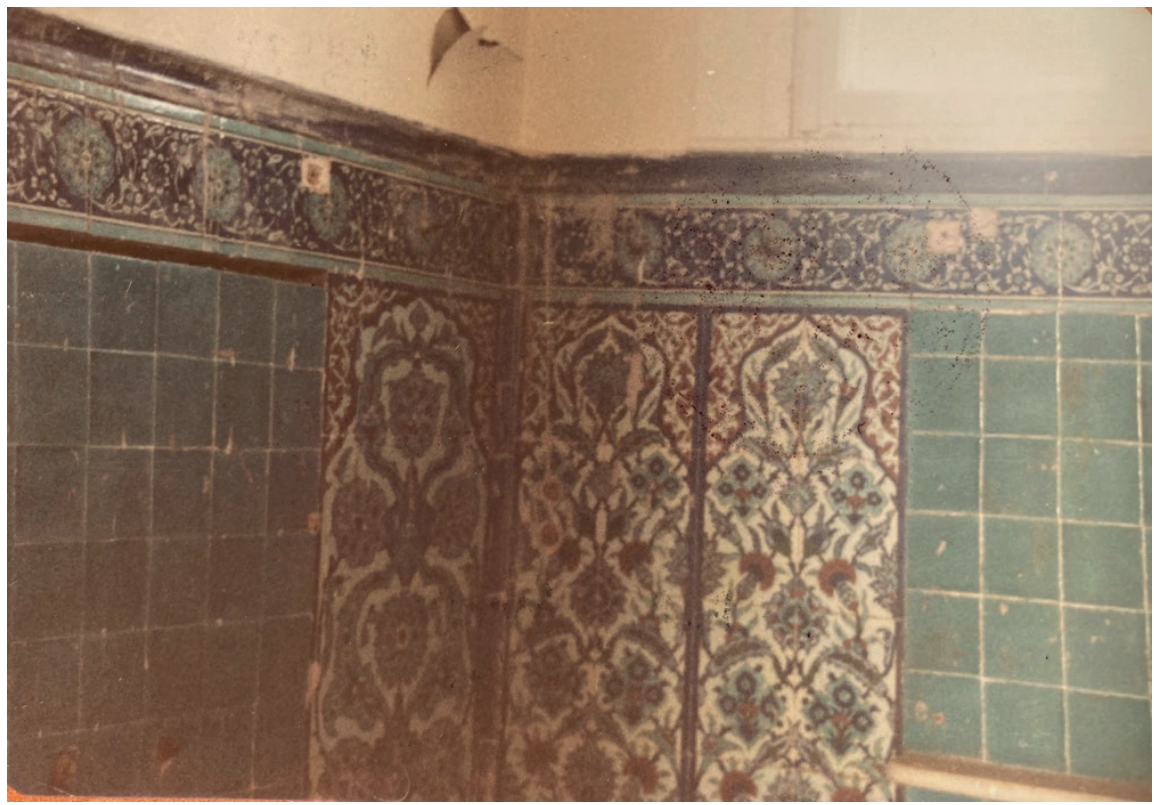

Görsel 21: Enver Paşa Köşkü hamamındaki çini kullanımı. (Yapının İstanbul III Numaralı Kültür Varlıklarını Koruma Kurulundaki dosyası.)

\section{Veliefendi Hipodromu Projesi}

Vedad Bey'in Harbiye Nezareti baş mimarı olarak üzerinde uzun süre çalıştığı bir başka proje, Veli Efendi Hipodromu projesidir. ${ }^{43}$ Savaşın sonra ermesi sebebiyle uygulanamamış hipodrom projesine ait herhangi bir görsel belgeye ulaşılamamıştır. Bununla beraber, Vedad Bey 20 Şubat 1930 tarihinde İsmet Paşa'ya yazdığı dilekçede, hipodrom projesinin hazırlama sürecinde incelemelerde bulunmak üzere Berlin'e gönderildiğini, döndüğünde istenen projeleri hazırladığını fakat savaşın bitmesi sebebiyle uygulama aşamasına geçilemediğini ifade etmiştir. ${ }^{4}$ Vedad Bey’in Almanya'ya gönderilmesi için izin verildiği bildirilen 7 Ekim 1918 tarihli belge $\mathrm{de}^{45}$ bu aktarımı doğrulamaktadır.

\section{E. Ordunun İhtiyaçlarını Tespit Etmek Üzere Batum'da Saha Çalışması}

Vedad Bey, 1918 yılında, içinde Enver Paşa'nın da bulunduğu kalabalık bir heyetle, Harbiye Nezareti baş mimarı sıfatıyla Batum'a gitmiştir. ${ }^{46}$ Birinci Dünya Savaşı'nın Osmanlı için

43 Özkan, "Mimar Vedat Tek," 48.

44 Bodrum Mimarlık Kitaplığı, Vedad Tek Arşivi, Süha Özkan ve Pelin Derviş Koleksiyonu. (Bkz. EK2)

45 Belgenin fotokopisi, yazarın koleksiyonu. (Bkz. EK3)

46 Nihat Tek'in 7 Kasım 1977 tarihli dilekçesinden aktaran Onur, “Mimar Vedad Tek,” 107. Enver Paşa’nın, 1918 yılında kalabalık bir ekip ile gerçekleştirdiği Batum ziyareti, Askeri Merkez Sinema Dairesi tarafından filme alınmıştır. Film TRT2 tarafından çevrimiçi olarak yayınlanmıştır. Bu filmde Vedad Bey’in herhangi bir görüntüsüne rastlanmamıştır. “Enver Paşa ile Şehzade Ömer Faruk Efendi’nin Batum Ziyareti,” erişim 31 Ocak 2021.

https://www.trt2.com.tr/tarih/tarihin-ruhu/tarihin-ruhu-or-enver-pasa-ve-sehzade-omer-faruk-efendinin-batum- 
sonlanmasından kısa süre önce, Nisan-Ekim 1918 arasında, Batum'un Osmanlı topraklarına katıldığı süreçte gerçekleşen gezi, Nihat Tek'in aktarımına göre 5 gün sürmüş ve Vedad Bey bu süreçte ordunun ihtiyaçlarını yerinde tespit etmiştir. Vedad Bey'in kısıtlı zaman içerisinde Batum'da ne tür projelerin ön hazırlığını yaptığı, araştırma kapsamında tespit edilememiştir.

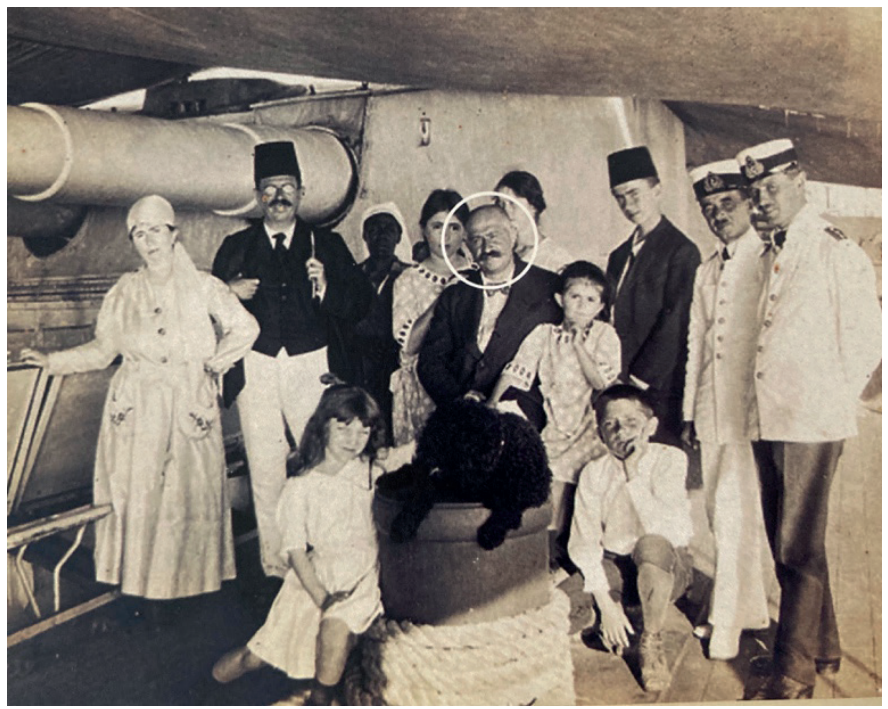

Görsel 22: Vedad Bey ve ailesi Yavuz zırhlısında. (Uğur Tanyeli, Mimarlığın Aktörleri Türkiye 1900-2000 (İstanbul: Garanti Galeri, 2000), 108)

\section{F. Askeri Mimarlık El Kitabı}

1914 yılı civarında ${ }^{47}$ "Umûm Kolordu Mıntıkaları Dâhilinde İnşa Olunacak Mebâni-i Mütenevvia-i Askeriye İçin İstimâl Olunacak Malzeme ve Tatbik Olunacak Tarz-1 İnşa Hakkında Tarifât-1 Umûmiyedir" başlıklı bir askeri mimarlık el kitabı yayınlanmıştır. Uğur Tanyeli, Vedad Bey'in bu kitaba katkıda bulunmuş olabileceğine veya kitabın kendisinin gözetiminde hazırlanmış olması gerektiğine dikkat çekmiştir. ${ }^{48}$ Kitapta, hepsi Milli Mimari üslubunda hazırlanmış bir grup tip projeye ilişkin toplam yetmiş adet çizim bulunmaktadır. Yapıların hemen hepsi simetrik ve çıkmalarla hareketlendirilmiş cephe düzenlerine ve her katta değişen kemer düzenine (genellikle sivri ve düz kemerler) sahiptir. Kitabın içeriği, tip projelerde Harbiye Nezareti'nin Milli Mimari üslubunu tercih ettiğini ortaya koymaktadır. Bununla beraber, kitaptaki çizimler, Vedad Bey’in hazırladığı üçüncü sınıf istasyon binasındaki tutum

ziyareti-or-41-bolum-131097

47 Söz konusu kitap, tam olarak tespit edilemeyen bir tarihte yayınlanmıştır. Uğur Tanyeli, kitabı 1915-1918 arasında tarihlemektedir. Uğur Tanyeli, Sınıraşımı Metinleri (İstanbul: Akın Nalça Kitapları, 2015), 356-357. Kitabın bu araştırma kapsamında incelenen kopyasında, 5 Haziran 1330 (18 Haziran 1914) tarihli bir damga; içerisinde ise "20 Mart 1330 tarihli tamim sureti” için ayrılmış bir sayfa bulunmaktadır. Bu veriler, kitabın 1914 yılında yayınlandığına işaret etmektedir.

48 Tanyeli, Sınırașımı, 357. 
ile uyumlu olup, Harbiye Nezareti'nce kabul gören tasarım anlayışını büyük bir yapı grubu üzerinden ortaya koyması bakımından dikkat çekicidir.

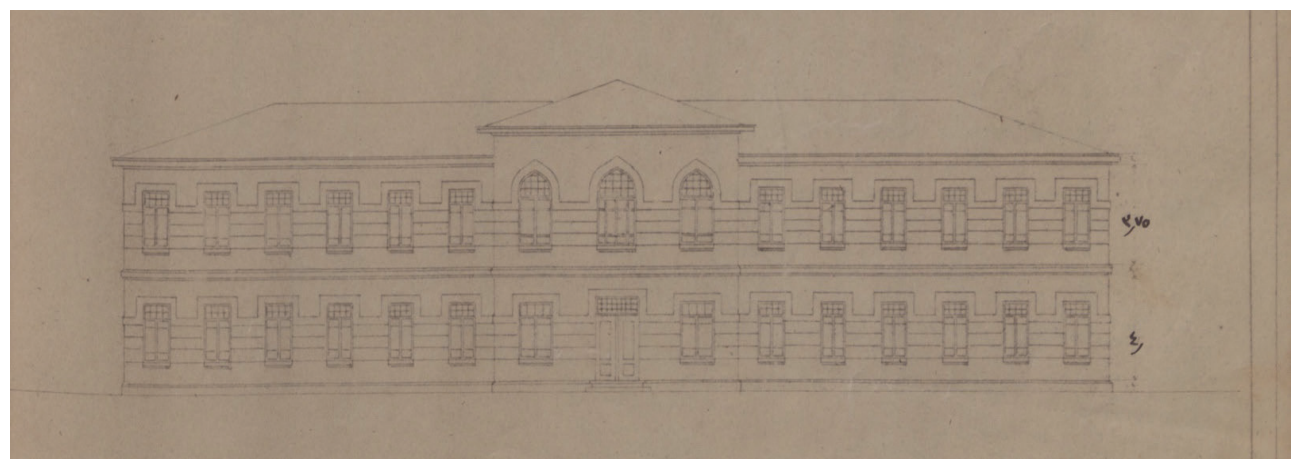

Görsel 23: "Alaylara mahsus kumandanlık dairesi” başlıklı tip proje. Umûm Kolordu Mıntıkaları Dâhilinde İnşa Olunacak Mebâni-i Mütenevvia-i Askeriye İçin İstimâl Olunacak Malzeme ve Tatbik Olunacak Tarz-1 İnşa Hakkında Tarifât-1 Umûmiyedir, 9 numaralı çizim)

\section{Sonuç}

Vedad Bey’in Harbiye Nezareti baş mimarı olarak çalışma koşullarına ilişkin ulaşılan veriler, mimari projelerin uygulama aşamasında Harbiye Nezareti'nin imkân ve elemanlarından faydalanıldığını göstermektedir. Haydarpaşa ve Moda iskelelerinin aksamlarının Harbiye Nezareti atölyelerinde üretilmiş olması, Sanayi-i Nefise Mektebi Mimarlık Şubesi öğrencilerinden Refik (Saydam) Bey'in Vedad Bey ile beraber çalışması ve Ankara-Sivas demiryolu hattının inşasında mühendis mektebi öğrencilerinden oluşan yedek subayların görev alması, bu durumu yansıtan verilerdir. İnşa süreçlerinde ihale usulüne başvurulup başvurulmadığına ilişkin bir belge tespit edilememekle beraber, Harbiye Nezareti’ndeki çalışma biçiminin, Vedad Bey'in projelerinin ağırlıklı olarak ihale usulüyle gerçekleştirildiği saray mimarlığı döneminden farklı olduğu anlaşılmaktadır.

Vedad Bey'in nezaret için çıktığı iki uzun yolculuk- Veliefendi Hipodromu'nu projelendirmeden önce Almanya'yı ve ordunun ihtiyaçlarını tespit etmek üzere Enver Paşa ile Batum’u ziyaret etmesibirkaç açıdan önemlidir. Hipodrom projesi için müttefik ülkelerden Almanya'ya gönderilmesi, söz konusu projeye nezaretçe önem verildiği ve savaş koşullarına rağmen yatırım yapılmasının planlandığını ortaya koymaktadır. Batum ziyareti ise, Vedad Bey'in görev kapsamının İstanbul ile sınırlı olmadığını göstermekte, imparatorluk sınırları içerisinde askeri ihtiyaçları tespit etmek üzere farklı şehirlerde de çalışmış olabileceğini akla getirmektedir.

Araştırma kapsamında, Vedad Bey tarafından Harbiye Nezareti için veya nezaret ile bağlantılı olarak hazırlanmış toplam altı proje görsel belgeleriyle ele alınmıştır. Bunlardan dördünün ulaşıma yönelik binalar olması, Harbiye Nezareti’nin görev alanını ve ihtiyaçlarını yansıtmaktadır. Geriye kalan iki örnekten Seyr-i Sefain Acentesi idari bir yapı iken, Enver Paşa Köşkü banisinin Harbiye Nezareti değil Harbiye Nazırı olduğu bir konuttur. 
Vedad Bey’in Harbiye Nezareti için tasarladığg yapıları, üslup açısından, Milli Mimari çerçevesinde fakat iki farklı alt grupta değerlendirmek mümkün görünmektedir. Vedad Bey, Milli Mimari üslubunun kurucu figürlerinden olmakla beraber, yukarıda da belirtildiği gibi hemen her yapısında farklı denemelerde bulunduğundan, yapıları belirli kurallar çerçevesinde kolaylıkla çözümlenemez. Dönem yapılarının karakteristik özelliklerinden olan simetrik cephe tasarımlarının yerine zaman zaman asimetrik düzenlemeleri tercih etmesi, yapılarda kullanılacak dekoratif elemanları ve çini kompozisyonlarını bizzat tasarlaması gibi eğilimleri, Harbiye Nezareti için çalıştı̆̆ı yıllarda Seyr-i Sefain İdaresi için projelendirdiği binalarda da izlenebilmektedir. Kendilerine has ve detayları üzerine incelikle düşünülmüş bu yapılardan Haydarpaşa İskelesi, zengin bir tarihsel referans yelpazesinden ilham alan yoğun taş ve çini bezemeleriyle, Moda İskelesi süsleme açısından çok daha sade fakat her biri farklı tasarlanmış cepheleriyle, Seyr-i Sefain Acentesi asimetrik cephe düzenlemeleriyle dikkat çeker.

Uygulanamamış olan “Üçüncü Sınıf İstasyon” projesi, Seyr-i Sefain İdaresi için tasarlanan yapılardan sadeliği bakımından ayrılmaktadır. Milli Mimari üslubunun ortak biçimlenme özelliklerini taşıyan bu yapı, savaş koşullarında tasarlamış, işlevselliği ön planda tutulmuş, gösterişli cephelere ve ince süsleme detaylarına sahip olmayan bir proje olarak değerlendirilebilir. Aynı yıllarda hazırlanmış olan Askeri Mimarlık El Kitabı'ndaki çizimlerle Vedad Bey'in -ve hatta Kemaleddin Bey'in- uygulanmayan istasyon projeleri beraber ele alındığında, Harbiye Nezareti'nce inşa ettirilecek tip projelerde Milli Mimari üslubunun sade örneklerinin tercih edildiği anlaşılmaktadır.

Vedad Bey’in Enver Paşa için inşa ettiği köşk, Vedad Bey ile Enver Paşa'nın iyi ilişkilerinin önemli bir göstergesidir. Milli Mimari üslubunun devlet eliyle inşa ettirilen yapılarda benimsendiği ve dönemin milliyetçi hareketleri bağlamında anlamlandırıldığı yıllarda, Vedad Bey'in Enver Paşa'ya, İttihat ve Terakki Cemiyeti'nin en güçlü figürlerinden birine, dış cephesinde Milli Mimari'den pek bir iz taşımayan bir konut tasarlaması son derece ilginçtir. Tasarım ve inşa süreçlerinde bani ile mimar arasındaki iletişime dair herhangi bir veriye ulaşılamadığından, yapının Enver Paşa'nın arzusuyla mı, Vedad Bey'in inisiyatifiyle mi bu şekilde projelendirildiğini tespit edilememiştir. Bununla beraber, Enver Paşa Köşkü, Vedad Bey’in tek bir üsluba veya tutuma indirgenemeyecek bir mimar olduğunu tekrar hatırlatmaktadır.

Hakem Değerlendirmesi: Dış bağımsız.

Çıkar Çatışması: Yazar çıkar çatışması bildirmemiştir.

Finansal Destek: Yazar bu çalışma için finansal destek almadığını beyan etmiştir.

Peer-review: Externally peer-reviewed.

Conflict of Interest: The author has no conflict of interest to declare.

Grant Support: The author declared that this study has received no financial support. 


\section{Kaynakça/References}

Anonim. Alaylara mahsus kumandanlık dairesi" başlıklı tip proje. Umûm Kolordu Mıntıkaları Dahilinde İnşa Olunacak Mebâni-i Mütenevvia-i Askeriye İçin İstimâl Olunacak Malzeme ve Tatbik Olunacak Tarz-ı İnşa Hakkında Tarifât-ı Umûmiyedir. Basım yeri ve yılı belirtilmemiş.

“Âbide-i Şühedâ.” Tanin, 3 Nisan 1914.

Arlı, Hakan.“Kütahyalı Mehmed Emin Usta ve Eserlerinin Üslubu.”Yüksek Lisans Tezi, İstanbul Üniversitesi, 1989.

Başar, Mehmet Emin Başar ve Erdoğan, Hacı Abdullah, “Osmanlı'dan Cumhuriyet'e Türkiye'de Tren Garları”, Selçuk Üniversitesi Mühendislik-Mimarlık Fakültesi Dergisi c.24 s.4 (2009): $29-44$.

Batur, Afife. "Kimliğinin İzinde I: Sermimarlığa Doğru," M. Vedad Tek Kimliğinin İzinde Bir Mimar, editör Afife Batur içinde 75-146. İstanbul: Yapı Kredi Yayınları, 2003.

Batur, Afife. "Kimliğinin İzinde II: Yeniyi Aramak." M. Vedad Tek Kimliğinin İzinde Bir Mimar, editör Afife Batur içinde 147-156. İstanbul: Yapı Kredi Yayınları, 2003.

Batur, Afife. "Son Olmaması Özlenen Bir Sonsöz." M. Vedad Tek Kimliğinin İzinde Bir Mimar, editör Afife Batur içinde 315-319. İstanbul: Yapı Kredi Yayınları, 2003.

Çerkez, Murat, “Kırıkkale Tren Garı Üzerine Bazı Tespitler”, Troyacademy 5 (2) (2020): 231-257.

Demirbel, Yusuf Razi.“Prof. Mimar M. Vedad Tek.” Arkitekt 129-130 (1941): 231-233.

Dönmez, Emel Emine. “Türk Çini Sanatının Sürekliliği İçinde XVII. Yüzyıl Eserlerinin Yeri.” Doktora Tezi, İstanbul Üniversitesi, 2001.

Erkan, Yonca Kösebay. “Anadolu Demiryolu Çevresinde Gelişen Mimari ve Korunması.” Doktora tezi, İstanbul Teknik Üniversitesi, 2007.

Göktaş Kaya, Lütfiye. "Karabük Kent Kimliği İçinde İstasyon Binasının Yeri,” XX. Uluslararası Ortaçağ ve Türk Dönemi Kazıları ve Sanat Tarihi Araştırmaları Sempozyumu Bildirileri içinde 504-518. Sakarya: 2016.

Gümüş, Müjde Dila. "II. Meşrutiyet’te Saray İçin Çalışmak: Vedad (Tek) Bey’in Sermimarlık Dönemi." Doktora tezi, İstanbul Üniversitesi, 2018.

Haykır, Yavuz. “Atatürk Dönemi Kara ve Demiryolu İnşa Çalışmaları. ” Doktora tezi, Fırat Üniversitesi, 2011.

Misawa, Nobuo. "Japon Ticaret Sergisi (1929-1937): İstanbul'daki Japon İzleri,” 1453 İstanbul Kültür ve Sanat Dergisi 7 ( 2010): 40-45.

Onur, Tülin. "Mimar Vedad Tek: Mimari Kişiliği ve Dönemin Mimarlık Sorunları.” Doktora tezi, Ankara Üniversitesi, 1988.

Özkan, Süha. “Mimar Vedat Tek (1873-1942),” Mimarlık 11-12 (Kasım-Aralık 1973): 45-51.

Özkan, Süha ve A. Nihad Vedad Tek, "Mimar M. Vedad Bey Konağı.” O.D.T.Ü. Mimarlık Fakültesi Dergisi 5, 2 (1979): 157-183.

Özkan, Süha. "Reddedilen Bir Mimar: Vedat Tek,” Şehir VII, (1987): 24-29.

Tanyeli, Uğur. Mimarlı̆̆ın Aktörleri Türkiye 1900-2000. İstanbul: Garanti Galeri, 2000.

Tanyeli, Uğur. Sinıraşımı Metinleri. İstanbul: Akın Nalça Kitapları, 2015.

Tek, Nihat. "N. Nahir Sılan'a Mektup.” M. Vedad Tek Kimliğinin İzinde Bir Mimar, editör Afife Batur içinde 385-394. İstanbul: Yapı Kredi Yayınları, 2003.

Tekeli, İlhan ve Selim İlkin. Mimar Kemalettin 'in Yazdıkları. Ankara: Şevki Vanlı Mimarlık Vakfı Yayınları, 1997. 
Tutel, Eser. Seyr-i Sefain Öncesi ve Sonrası. İstanbul: İletişim Yayınları, 1997.

Uluç, Lale. "M. Vedat Tek, Architect: An Episode in Turkish Architecture.” Yüksek lisans tezi, Boğaziçi Üniversitesi, 1987.

Ünsal, Behçet. “70 Yaşını İdrak Eden Mimarlar II: Boğaziçi’nde Bir Mimar,” Arkitekt 352 (1973): 178-180

Yavuz, Yıldırım. Mimar A. Kemalettin Imparatorluk'tan Cumhuriyet'e. Ankara: TMMOB Mimarlar Odası ve Vakıflar Genel Müdürlüğü Yayınları, 2009.

\section{Arşiv Belgeleri}

Cumhurbaşkanlığı Devlet Arşivleri, Osmanlı Arşivi (BOA), PLK.p.03154, 2 Mayıs 1331 (11 Haziran 1915); PLK.p.03439 (tarihsiz); PLK.p.05105, Şubat 1331 (Şubat-Mart 1916); PLK.p.03045, Şubat 1331 (ŞubatMart 1916); PLK.p 03358, 28 Teşrinisani 1331 (11 Aralık 1915); PLK.p 03187, 28 Teşrinisani 1331 (11 Aralık 1915); PLK.p.03053, 19 Ağustos 1331 (1 Eylül 1915); PLK.p.03053, 28 Teşrinisani 1331 (15 Aralık 1915), DH.İ.UM.EK.17/73, 16 Temmuz 1332 (29 Temmuz 1916).

İstanbul, Beşiktaş, Ortaköy, 21 pafta, 35 ada, 140 parselde bulunan Enver Paşa Köşkü’nün İstanbul III Numaralı Kültür Varlıklarını Koruma Kurulundaki dosyası. 
EK 1: Vedad Bey 3 Kanunusani 1339 (3 Ocak 1923) tarihinde İstanbul Kumandanlığına yazdığı dilekçe. Bodrum Mimarlık Kitaplığı, Vedad Tek Arşivi, Süha Özkan ve Pelin Derviş Koleksiyonu

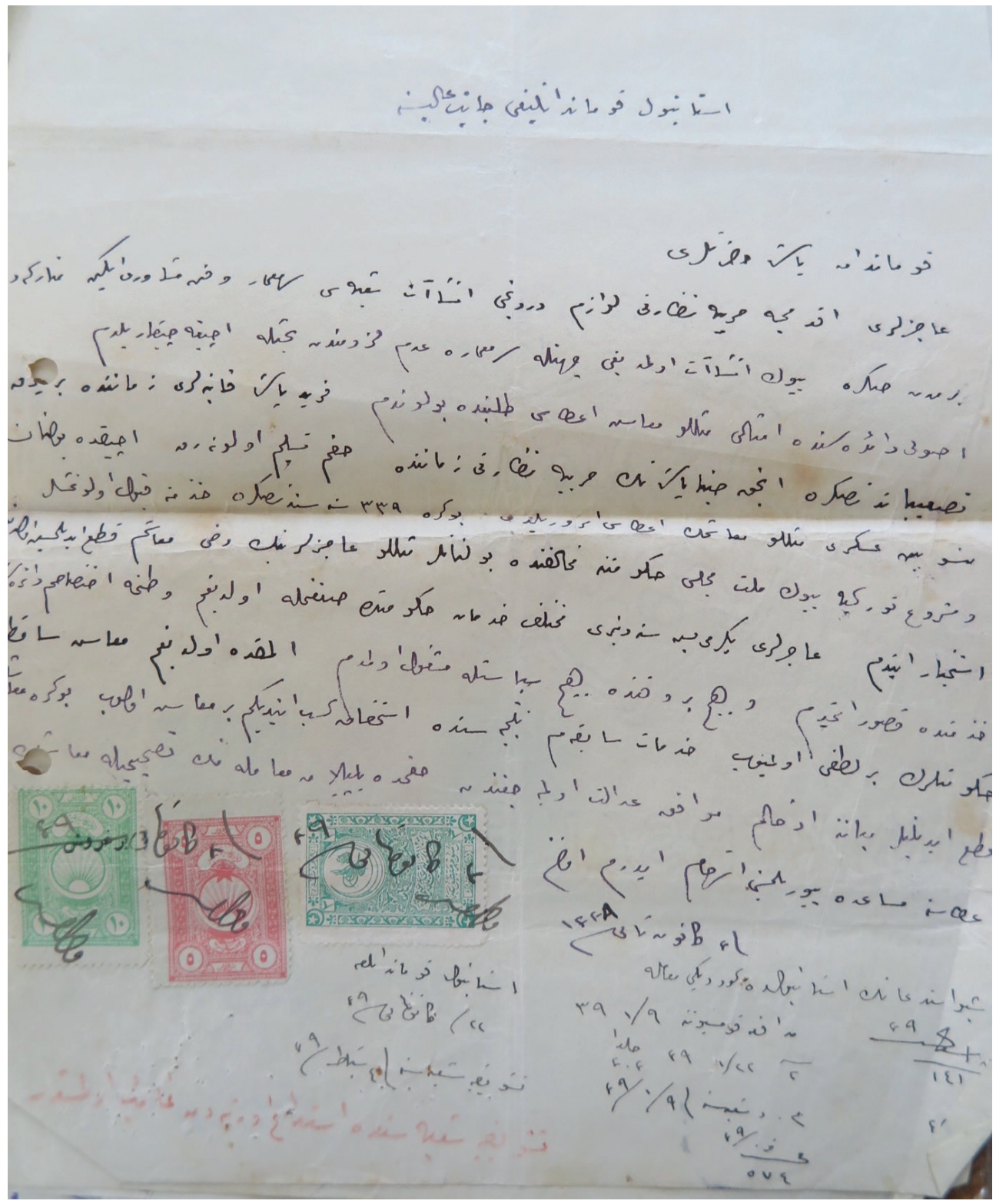


EK 2: Vedad Bey'in 20 Şubat 1930 tarihinde İsmet Paşa'ya yazdığ dilekçe. Bodrum Mimarlık Kitaplığı, Vedad Tek Arşivi, Süha Özkan ve Pelin Derviş Koleksiyonu

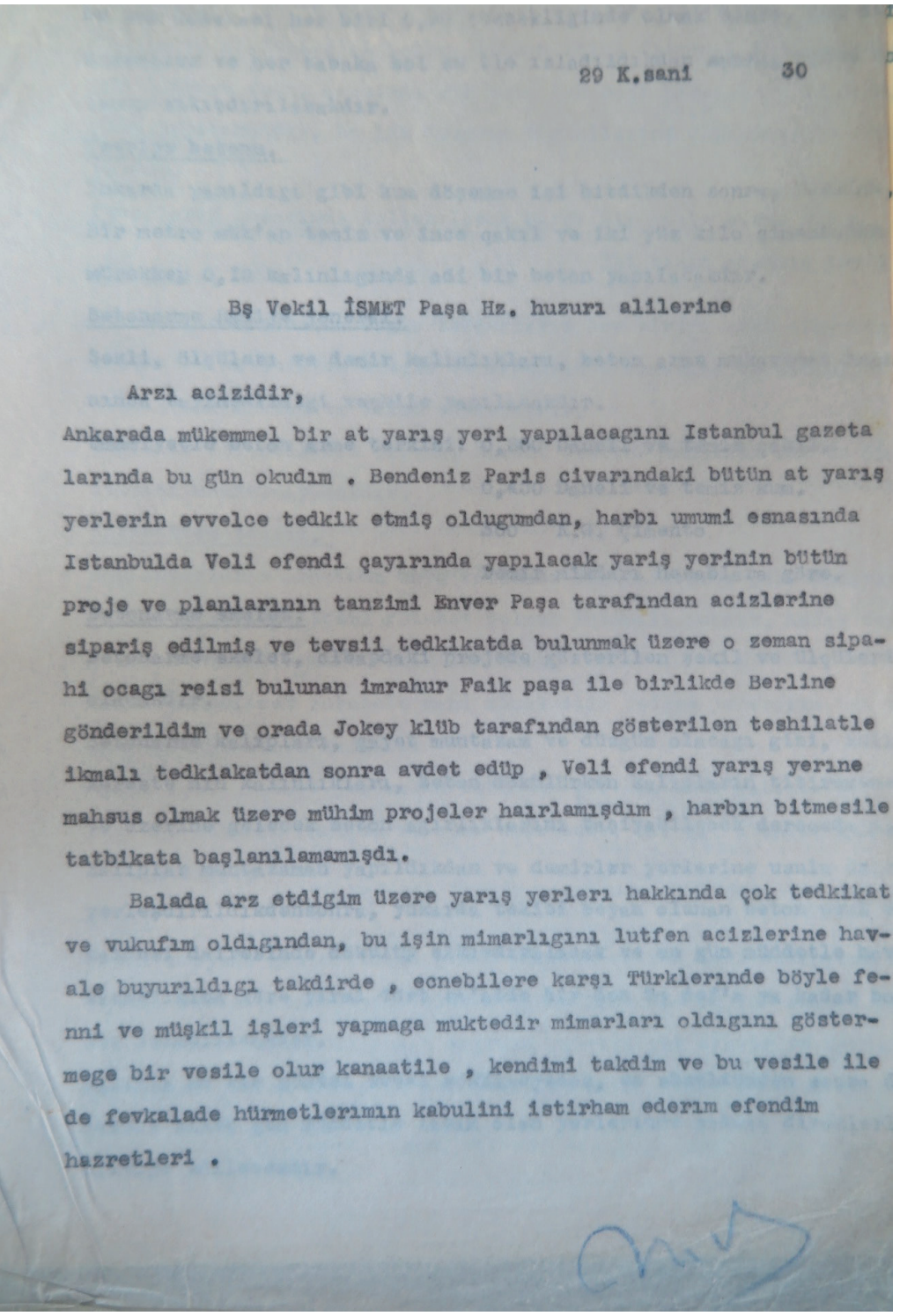


EK 3: Vedad Bey'in Almanya'ya gönderilmesi için izin verildiği bildirilen 7 Teşrinievvel 1334 (7 Ekim 1918) tarihli belgenin fotokopisi, yazarın koleksiyonu

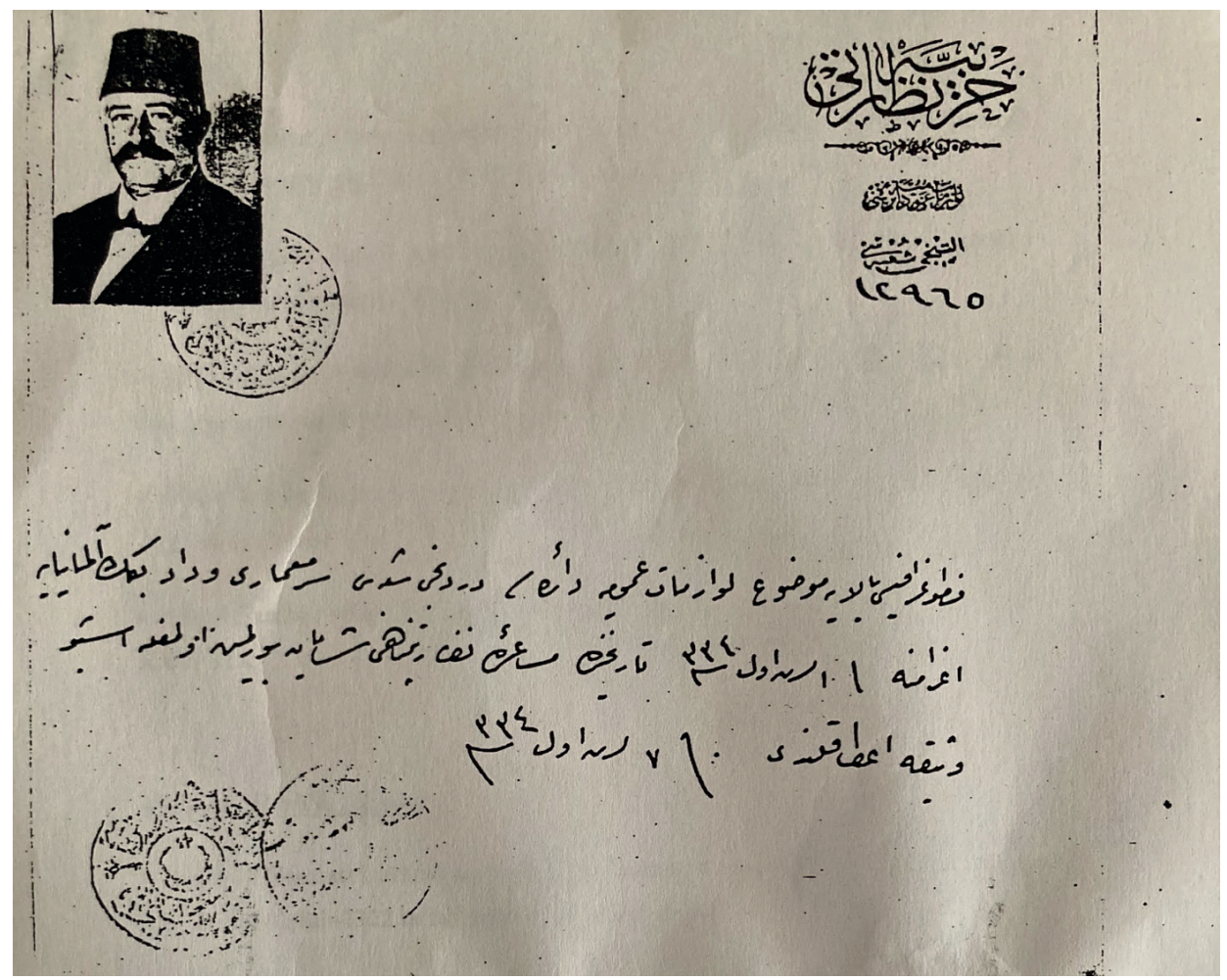


